\title{
İklim Değişikliğinin Havza Ölçeğinde Akım ve Sediman Miktarına Etkilerinin Değerlendirilmesi: Yuvacık Baraj Gölü Havzası
}

\author{
Evaluation of Climate Change Impacts on Runoff and Sediment at the Basin Scale:
}

\author{
Yuvacık Dam Lake Basin
}

\author{
Ayfer ÖZDEMIR $\mathbb{D}$ \\ Helmholtz Centre for Environmental Research-UFZ Department of Computational Landscape Ecology \\ Permoserstr. 15 D - 04318 Leipzig, Germany \\ Tarım ve Orman Bakanlı̆gl, Su Yönetimi Genel Müdürlüğü, \\ Taşkın ve Kuraklık Dairesi Başkanlı̆̆l, Söğütözü Ankara, Türkiye
}

Geliş (Received): 30 Mart (March) 2020 / Düzeltme (Revised): 06 Ağustos (August) 2020 / Kabul (Accepted): 15 Ağustos (August) 2020

\section{ÖZ}

İklim değişikliğinin hidrolojik etkilerinin kantitatif tahminleri, gelecekteki sel ve kuraklık gibi su kaynağ1 problemlerinin anlaşılması ve dolayısıyla bunların yönetilmesinin sağlanmasında yararlıdır. Bu çalışmanın amacı, iklim değişikliğinin nehir akışına etkisini belirlemeye yönelik bir çalışmanın ön sonuçlarını sunmak ve iklim değişikliğinin olumsuz etkilerinin azaltılmasına yönelik sürdürülebilir havza yönetimi politikalarının hazırlanabilmesi için muhtemel kentsel su kullanımı ve çevresel etkilerini değerlendirmektir. Bu kapsamda, öncelikle Toprak ve Su Değerlendirme Aracı (SWAT), Marmara Bölgesi’ndeki Yuvacık Baraj Gölü havzasında çalıştırılarak mevcut hidrolojik durum ortaya konmuştur. Meteoroloji Genel Müdürlüğü tarafindan Türkiye için Temsili Konsantrasyon Rotaları (RCP: Representative Concentration Pathways), RCP 4.5 ve RCP 8.5, senaryolarına göre üretilen $20 \mathrm{~km}$ çözünürlüklü iklim değişikliği projeksiyon verileri kullanılarak hidrolojik model 2021-2099 yılları arasında çalıştırılmıştır. Böylece, söz konusu yıllar arasında iklim değişikliğinin su ve sediman miktarına etkisi tahmin edilmeye çalışılmıştır. RCP 4.5 ve RCP 8.5 senaryolarına göre yıllık ortalama yă̆ış miktarlarında $2.23 \%$ ve $2.062 \%$ azalma, ve sıcaklık değerlerinde 1.24 ve $0.03^{\circ} \mathrm{C}^{\prime}$ lik artış tahmin edilmekte olup, Nisan ve Ağustos ayları arasında yağış miktarlarında artış olması beklenmektedir. Havzadaki Yuvacık Barajı'nı besleyen Kazandere, Kirazdere ve Serindere derelerinin 2006-2014 yıllarında ölçülen aylık ortalama akım değerleri sırasıyla, 0.55, 1.28 ve $1.94 \mathrm{~m}$ 3/s'dir. Bu değerler, 2021-2099 yılları için RCP 4.5 ve RCP 8.5 senaryolarına göre modellenen akım değerleriyle karşılaştırıldığında, sırasıyla Kazandere 0.14 ve $0.17 \mathrm{~m}^{3} / \mathrm{s}$, Kirazdere 0.41 ve $0.33 \mathrm{~m}^{3} / \mathrm{s}$, Serindere 0.86 ve $0.68 \mathrm{~m}^{3} / \mathrm{s}^{\prime}$ dir. Bu sonuçlar, barajı besleyen derelerin akım debilerinde azalma olacağını göstermektedir. Ayrıca, özellikle Kazandere ve Serindere pik akım değerlerinde yaklaşık $8 \mathrm{~m}^{3} / \mathrm{s}^{\prime} \mathrm{den} 2 \mathrm{~m}^{3} / \mathrm{s}$ 'ye ciddi miktarlarda azalma olduğu tahmin edilmiştir. Serindere istasyonunda 2010-2014 yılları için ölçülen yaklaşık aylık ortalama 49 ton sediman miktarı 2021-2099 yılları için RCP 4.5 senaryosuna göre aylık ortalama 247.58 ton ve RCP 8.5 senaryosuna göre 332.21 ton olarak hesaplanmıştır. Her iki senaryoya göre, Nisan ve Ağustos ayları arasındaki tahmin edilen yağış miktarında artış ve sıcaklık değerlerinde yükselme, havzada mekanik erozyona sebep olacaktır. $\mathrm{Bu}$ nedenle, akımla taşınan sediman miktarının artması beklenmektedir. Yuvacık Barajı Sakarya ve İzmit illerinin içme suyu ihtiyacını karşılamanın yanısıra, sulama, sel ve taşkın önleme ve kuraklık dönemlerinde su yönetimi sağlamak üzere kullanılmaktadır. Bu nedenle, baraj gölünü besleyen derelerin debi değerlerindeki azalma, baraj gölünün su hacminde azalmaya sebebiyet verecek olup, baraj gölünden sulanan alanlardaki ürün deseni ve içme suyu kullanımı için geleceğe yönelik su yönetim planlaması yapılması gerekmektedir. Ayrıca, baraj gölünü besleyen derelerin debilerinde düşüş havzadaki orman alanlarının azalmasına, orman alanlarının azalması erozyon miktarında 
Özdemir

artışa sebep olacaktır. Bu durum, baraj gölüne gelen sediman miktarının artışına sebep olacağı için baraj gölünün kullanım süresi kısalacaktır.

Anahtar Kelimeler: İklim Değiş̧ikliği, Hidroloji, SWAT, RCP 4.5, RCP 8.5, Yuvacık Baraj1

\section{ABSTRACT}

Quantitative estimations of climate changes on hydrological processes help to understand and manage water resource problems such as floods and droughts in the future. This study aims to present the preliminary results of a study to determine the impact of climate change on river flow to develop sustainable watershed management plans and to evaluate the possible urban water use and environmental impacts to prepare policies to mitigate its negative impacts. In this study, the Soil and Water Assessment Tool (SWAT) was used as a hydrological model to predict hydrological effects of climate change to better understand and solve future water resource problems. In this context, firstly the Soil and Water Assessment Tool (SWAT) was operated on the Yuvactk Dam Basin in Marmara Region to reveal the present hydrological situation. The hydrological model was then simulated by using the climate change data that have $20 \mathrm{~km}$ spatial resolution between 2021-2099 years based on RCP 4.5 and RCP 8.5 scenarios that were produced by the General Directorate of Meteorology. Thus, the effects of climate change on the amount of water and sediment were estimated between these years. According to the RCP 4.5 and RCP 8.5 scenarios, 2.23\% and $2.062 \%$ decrease in the average annual rainfall, and 1.24 and 0.03 of increase in temperature values were predicted, respectively. However, an increase in precipitation was expected between April and August. The average monthly flows (between 2006-2014) of the Kazandere, Kirazdere and Serindere rivers recharging the Yuvactk Dam in the basin is 0.55, 1.28 and $1.94 \mathrm{~m}^{3} / \mathrm{s}$, respectively. Corresponding modelled flow values based on RCP 4.5 and RCP 8.5 scenarios for 2021-2099 period, for Kazandere, Kirazdere and Serindere are 0.14 and $0.17 \mathrm{~m}^{3} / \mathrm{s}, 0.41$ and $0.33 \mathrm{~m}^{3} / \mathrm{s}, 0.86$ and $0.68 \mathrm{~m}^{3} / \mathrm{s}$, respectively. These values show significant decrease in flow rates of the rivers in the future. Moreover, the peak flow values of the streams especially for Kazandere and Kirazdere decrease from 8 to $2 \mathrm{~m}^{3} / \mathrm{sec}$. The amount of the monthly average of sediment measured at the Serindere stream station for the years 2010-2013 was 49 tons, while it was calculated as 247.58 tons based on RCP 4.5 and 332.21 tons based on RCP 8.5 for 2021-2099 period. According to both scenarios, an increase in the predicted rainfall between April and August, and an increase in temperature will cause mechanical erosion in the basin. Thus, the amount of sediment carried by flow is expected to increase. The Yuvack Dam is used for providing irrigation and drinking water requirements of Sakarya and Izmit provinces, and for the prevention of flood as well as for water management during drought periods. Therefore, the decrease in the flow rates of the streams recharging the dam will cause a decrease in the water volume of the dam, hence the future water management planning should be made for the crop pattern in the irrigated areas of the dam and for the drinking water usage. Furthermore, the decrease in the flow rates will cause to decrease the forest areas in the basin and which in turn will lead to an increase in the amount of erosion. This will cause an increase in the amount of sediment coming to the reservoir thus the service life time of the reservoir will be shortened.

Keywords: Climate Change, Hydrology, SWAT, RCP 4.5, RCP 8.5, Yuvactk Dam

\section{GİRİ̧}

İklim değişikliği doğrudan ve dolaylı olarak, ekolojik sistemleri ve dünyadaki insan refahını etkileyecektir (IPCC, 2000; IPCC, 2014; Melillo vd., 2014). İklim değişiminin bölgesel hidrolojik koşulları değiştirmesi beklenmektedir (Uniyal vd., 2015; Chaemiso vd., 2016; Song vd., 2018; Bhatta vd., 2019). Hidrolojik süreç üzerindeki potansiyel etkiler buharlaşma, toprak nemi, su sıcaklığı, akış hacmi, akış zamanlaması ve büyüklüğü ile sılı̆ğı üzerinde olabilir (Arnell vd., 2014; Otto 2019; Sattar vd., 2020). İklim değişikliğinin yağış, buharlaşma ve akış üzerinde doğrudan etkisi bulunduğundan hidrolojik döngüde değişiklikler meydana gelecek, ve bu durum sel ve kuraklık gibi felaketlerin sıklığını ve yoğunluğunu artıracaktır. Dolayısıyla, iklim 
değişikliğinin hidrolojik etkilerine ilişkin kantitatif tahminler, su kaynağ 1 problemlerinin anlaşılmasında ve yönetilmesinde faydalı olacaktır. İklim değişikliğinin su kaynaklarının hidrolojik koşullarına etkilerini gözlemlemek için hidrolojik modeller kullanılmaktadır (Gosain vd., 2006). Hidrolojik modeller, iklim parametreleri, antropojenik aktiviteler ile su kaynakları arasındaki ilişkileri değerlendirmek ve akış miktarlar1, su verimleri, evapotranspirasyon miktarı, sediman ve besin kayıplarını tahmin etmek için bir temel sunar. SWAT (Toprak ve Su Değerlendirme Aracı: Arnold vd., 1998) modeli, nehir havzalarının hidrolojik modellemesi için sıklıkla kullanılmaktadır. Örneğin, SWAT kullanılarak, gelecekteki iklim değişikliğinin tarımsal su sağlama kapasitelerine etkileri (Ahn vd., 2015), iklim değişikliğinin akış, sediman ve besin miktarına olan etkileri (Verma vd., 2015), iklim değişikliğinin hidrolojik rejim üzerine etkileri(Panday vd., 2018) ve iklim değişikliğinin akış rejimine etkisi (Song vd., 2018) çalışılmıştır. İklim değişikliğinin hidrolojik etkilerine yönelik çalışmalar ülkemiz coğrafyasında da yapılmaktadır (Yılmaz ve Yazıcıgil, 2011; Kara ve Yücel, 2015; Kara vd., 2016; Yagbasan, 2016; Yagbasan vd., 2017; Sönmez ve Kale, 2018; Alp ve Özcan, 2017; Bucak vd., 2018).

$\mathrm{Bu}$ çalışmada, iklim değişikliği etkilerinin havza ölçeğinde değerlendirilerek, sürdürülebilir su yönetiminin sağlanması maksadıyla; Sakarya nehir havzasının Yuvacık Baraj Gölü alt havzasını besleyen derelerdeki iklim değişikliğinin akış debisine ve sedimanmiktarına etkisi SWAT modeli kullanılarak belirlenmiştir. Kullanılan yöntem (1) havzanın SWAT modelinin oluşturulması, (2) FACT (Hizlı Otomatik Kalibrasyon Arac1; Ozdemir ve Leloğlu, 2018) kullanılarak modelin kalibrasyonunun yapılması, (3) havzada iklim değişikliğinin su kaynaklarına olan etkisini incelemek için, Meteoroloji Genel Müdürlüğü tarafından Türkiye için Temsili Konsantrasyon Rotaları (RCP: Representative Concentration Pathways), RCP 4.5 ve RCP 8.5 iklim değişikliği senaryolarına göre üretilen verileri kalibre edilmiş hidrolojik modelde kullanarak, hidrolojik modelin çalıştırılması, (4) iklim değişikliğinin dere akım debisine ve sediman miktarına olan etkilerinin tahmin edilmesi ve (5) söz konusu alandaki su kaynaklarına iklim değişikliği etkilerinin belirlenmesi, ve konuyla ilgili daha fazla araştırma için zemin hazırlanması şeklindedir. Yuvacık Barajı, ham su depolama, sel ve taşkın önlemenin yanısıra kurak dönemlerde su yönetimi sağlamak üzere inşa edilmiştir. İçme suyu barajı olması nedeniyle, havzadaki sürdürülebilir su yönetimini sağlamak, barajdan etkin su temini ile mümkündür.

\section{MATERYAL VE YÖNTEM Çalışma Alanı}

Yuvac1k Havzasi, 40032'-40041' kuzey enlemleri ve $29^{\circ} 49^{\prime}-30^{\circ} 08^{\prime}$ doğu boylamları arasında, Kocaeli ili İzmit ilçesinin yaklaşık 16 km güney doğusunda Sakarya havzası içerisinde yer almaktadır (Şekil 1).

Yuvacık Barajı Havza Koruma ve Özel Hüküm Belirleme projesi (YBOZHP, 2016) kapsamında elde edilen jeolojik, hidrolojik, hidrojeolojik, meterolojik veriler bu çalışmada kullanılmıştır. Yuvacık Barajı, ham su depolama, sel ve taşkın önleme amaçları yanında kurak dönemlerde su yönetimi sağlamak üzere kullanılmaktadır. Kocaeli Büyükşehir Belediyesi ISU Genel Müdürlüğü tarafından 2006 yılında yaşanan kuraklık nedeniyle, Sapanca Gölü'nden Yuvacık Barajı'na ham su desteği vermek üzere Sapanca Gölü terfi sistemi kurulmuştur. Ayrıca, 2014 y1lında İzmit'in su ihtiyacını kuraklık döneminde sağlamak amaciyla yaklaşık 80 adet kuyu açılmış ve alüvyon akiferinden alınan yeraltı suyu arıtma tesisine iletilmiştir. 




Şekil 1. Çalışma alanı ve Yuvacık Barajını besleyen önemli dereler.

Figure 1. The study area and important streams that recharge the Yuvactk Dam. 
Kocaeli ili ve çevresine içme suyu sağlamak amacıyla inşa edilen barajın toplam beslenim alanı $257.86 \mathrm{~km}^{2}$ 'dir. Baraj su yönetimi açısından dört alt havzaya ayrılmıştır (Şekil 1). $\mathrm{Bu}$ havzalardan üçü baraj gölünün besleniminde önemli payı olan Kirazdere, Serindere ve Kazandere alt havzalarıdır. Bu alt havzaların dışında baraj yönetimi açısından ara havza olarak tanımlanan baraj gölünü çevreleyen bir havza daha yer almaktadır. Serindere 120.33 $\mathrm{km}^{2}$ lik beslenme alanı ile en büyük alt havzayı oluşturmakta, onu sirasiyla $79.54 \mathrm{~km}^{2}$ ile Kirazdere, $23.10 \mathrm{~km}^{2}$ ile Kazandere ve 34.69 $\mathrm{km}^{2}$ ile ara havza takip etmektedir. Barajın y1llık debisi 220.8 milyon m³/yıl'dır (Çizelge 1). Yuvacik havzasına giren akımların ortalama $\%$ 36's1 Serindere'den (60.44 milyon $\left.\mathrm{m}^{3}\right)$, \% 28'i Ara Havza'dan (47.41 milyon $\mathrm{m}^{3}$ ), \% 24'ü Kirazdere'den (39.59 milyon m³), \% 10'u Kazandere'den (17.01 milyon $\left.\mathrm{m}^{3}\right)$, \% 2'si (3.5 milyon $\mathrm{m}^{3}$ ) ise ISU Ara depodan (Şekil 1: FP4) kaynaklanmaktadır. Havzada pekçok yeraltısuyu kaynağı bulunmaktadır. Kaynaklardan gelen fazla su ISU Ara depoda depolanarak baraja tahliye edilmektedir. Yuvacık rezervuarından yıllık ayrılan su miktarını, arıtma tesisine alınan ham su, baraj radyal kapaklarından deşarj edilen su, tarımsal amaçlı salınan telafi suyu, Sapanca gölüne gönderilen ham su ve buharlaşma kayıpları oluşturmaktadır. Baraj rezervuarından çıkan yıllık ortalama akım miktarı 168.20 milyon $\mathrm{m}^{3}$ 'dür. Baraj rezervuarından farklı amaçlarla y1llk birakılan ortalama su hacminin \% 67'sini arıtma tesisine alınan (111.8 milyon $\mathrm{m}^{3}$ ), \% 32'sini radyal kapaklarından deşarj edilen (53.56 milyon $\mathrm{m}^{3}$ ), \% 0.7'sini tarımsal amaçlı salınan telafi suyu (1.16 milyon $\mathrm{m}^{3}$ ) ve \% 0.41'ni Sapanca gölüne gönderilen ham su miktarını (0.69 milyon $\mathrm{m}^{3}$ ) oluşturmaktadır.
Çizelge 1. Yuvacık Barajı'nın özellikleri.

Table 1. Properties of the Yuvacik Dam.

\begin{tabular}{l|l}
\hline $\begin{array}{l}\text { Yuvacık Barajı Toplam Drenaj Alanı } \\
\left(\mathrm{km}^{2}\right)\end{array}$ & 257.86 \\
\hline Kirazdere Drenaj Alanı $\left(\mathrm{km}^{2}\right)$ & 79.54 \\
Kazandere Drenaj Alanı $\left(\mathrm{km}^{2}\right)$ & 23.10 \\
Serindere Drenaj Alanı $\left(\mathrm{km}^{2}\right)$ & 120.53 \\
Ara Havza $\left(\mathrm{km}^{2}\right)$ & 34.69 \\
Minimum su kotu $(\mathrm{m})$ & 112.50 \\
Maximum su kotu $(\mathrm{m})$ & 169.68 \\
Yıllık Debi ( Milyon $\left.\mathrm{m}^{3} / \mathrm{y} 1 \mathrm{l}\right)$ & 220.8 \\
\hline
\end{tabular}

Yuvacık Barajı havzasında makro tipi Akdeniz iklimi hüküm sürmektedir. Karadeniz iklimi Samanlı Dağları'nın körfeze bakan yamaçlarında görülmektedir. Havzada Kocaeli Büyükşehir Belediyesi tarafından kurulan 12 meteoroloji istasyonundan 2006-2015 y1llar1 arasında yapılan ölçümlere göre, en düşük sicaklık Şubat ayında görülmekte, ortalama güneşlenme süresi yazın 8 saat, kışın ise yaklaşık 3 saattir. Ortalama nispi nem değerleri bölgede yaz aylarında \%60-65, kış aylarında ise \%70-75 değerleri arasında değişmektedir. Y1llık ortalama toplam yağış 1061.46 mm'dir. Havzanın en fazla günlük yağış aldığı aylar Ekim, Kasım, Aralık, Ocak ve Şubat ayları olup, en fazla yağışın düştüğü ay $108 \mathrm{~mm}$ ile Aralık ayıdır. Haziran, Temmuz, Ağustos ve Eylül aylarında yağışın az olduğu (Şekil 2), buharlaşmanın yüksek olduğu gözlenmektedir. Havza içerisinde bulunan Kirazdere, Serindere ve Kazandere baraj1 besleyen önemli derelerdir ve yıl boyu sürekli akım karakteri sergilemektedir. Derelerin 2006- 2014 yılları arasında ölçülen günlük akım verileri incelendiğinde, derelerin maksimum akımları genellikle Şubat-Mart aylarında gözlenirken, en düşük akımlar baz akımların nehir akımına katkısının yüksek olduğu, MayısEylül ayları arasında görülmektedir. Ekim ve 
Ocak aylarında da yağışlara bağlı olarak pik akımlar gözlenmektedir (Şekil 3).

Serindere Yuvac1k Havzası'nda debisi en yüksek dere olup, bunu sirasiyla Kirazdere ve Kazandere takip etmektedir. 2006-2014 y1llarına ait gözlenen günlük dere akım verileri istatistiksel açıdan değerlendirildiğinde, Serindere $1.94 \mathrm{~m}^{3} / \mathrm{sn}$, Kirazdere $1.28 \mathrm{~m}^{3} / \mathrm{sn}$ ve Kazandere $0.55 \mathrm{~m}^{3} / \mathrm{sn}$ ' lik ortalama debiye sahiptir. 2006-2014 yıllarında arasındaki 9 yıllık gözleme dayalı olarak, Serindere'de $25.77 \mathrm{~m}^{3} /$ sn, Kirazdere'de $20.28 \mathrm{~m}^{3} / \mathrm{sn}$, Kazandere'de ise $7.31 \mathrm{~m}^{3} / \mathrm{sn}$ pik akım değerleri Ekim, Ocak ve Şubat aylarında gerçekleşmiştir. Minimum akım değerleri Ağustos ayında ölçülmüştür ve 0.01-0.06 m³ $/ \mathrm{sn}$ arasında değişmektedir (Şekil 3). Derelerin değişkenlik katsayılarının benzer olması (1.2-1.33), akım değerlerinin değişmesine rağmen akım rejimini kontrol eden havza özelliklerinin benzer olduğunu işaret etmektedir. Derelerin debi değerlerindeki değişkenlik miktarı (varyans) Serindere'de en yüksek $\left(\sigma^{2}=\right.$ 6.31) Kazandere'de en düşük $\left(\sigma^{2}=0.57\right)$ olarak hesaplanmıştır. Kirazdere'de bu değer $\sigma^{2}=3.21$ olarak belirlenmiştir.

\section{HIDDROLOJI MODELI}

SWAT ile modellenen Yuvacik havzas1 bir dizi alt havzaya bölünmüştür. Her bir alt havza, farklı arazi kullanımı, toprak tipi ve eğim kombinasyonlarından oluşan Hidrolojik İşlem Birimleri'ne (HİB) ayrılmıştır. Su dengesi, HİB seviyesinde hesaplanır ve daha sonra tüm alt havzada toplanır. SWAT'taki hidrolojik süreç simülasyonu iki adımda gerçekleşir: (1) model, her HİB' den akış debisi, sediman, besin, bakteri ve pestisit yüklerini hesaplar ve daha sonra alan ağırlıklı HİB seviyesindeki yükleri alt havza seviyesinde birleştirir ve (2) model, her bir alt havzadan gelen yükleri kanal/akış ağı üzerinden öteler (Gassman vd., 2007).

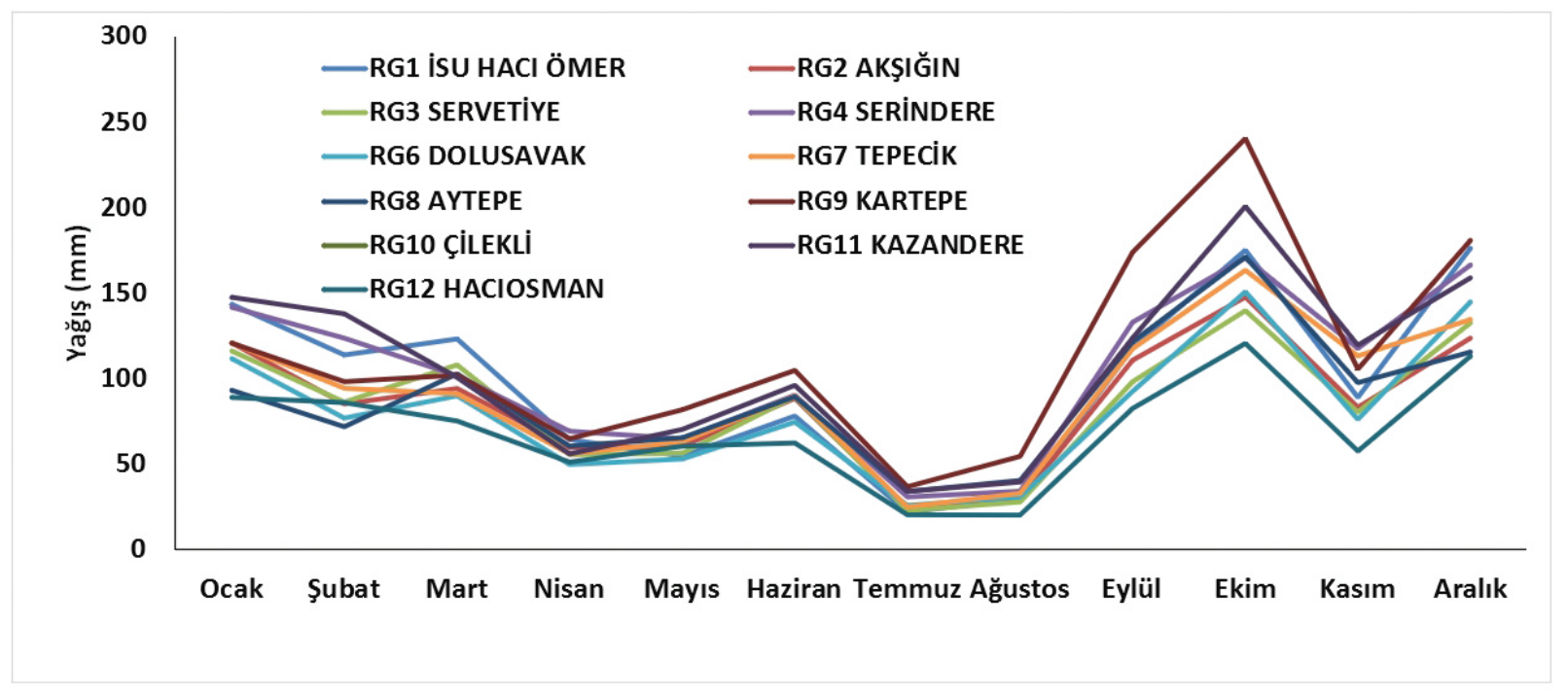

Şekil 2. Yuvacık Havzasındaki meterolojik istasyonlarında ölçülen ortalama aylık yağış toplamı.

Figure 2. Average total monthly rainfall measured at meteorological stations in the Yuvacik Basin. 


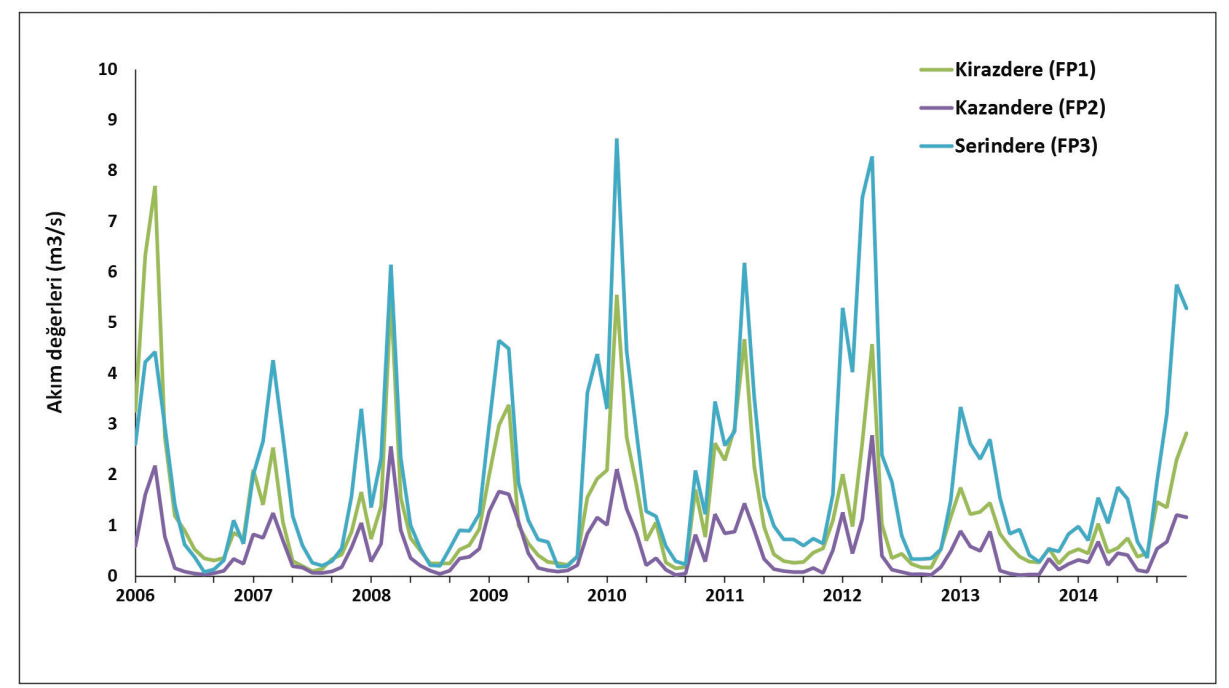

Şekil 3. Serindere, Kirazdere ve Kazandere akarsularına ait gözlenen aylık ortalama akım değerleri (Ocak 2006-Ağustos 2015).

Figure 3. Observed monthly average flow values of Serindere, Kirazdere and Kazandere streams (January 2006-August 2015).

\section{MODEL GIRDİ VERILERİ}

Yuvacık Barajı'nın havza sınırını belirlemek için sayısal arazi modeli kullanılmıştır. Sayısal arazi modeli (SAM) 1/25.000 ölçekli topografik haritalar kullanılarak 30x30 m çözünürlükte oluşturulmuştur (Şekil 4a). Sayısal arazi modeli haritasına göre; arazi yükseklik değerleri 140 ile $1530 \mathrm{~m}$ arasında değişmektedir. Havzada bulunan derelerin ana kollarının belirlenmesi amaciyla haritada farklı eşik değerleri denendiğinde, en uygun 200 ha eşik değeri bulunmuştur. Bu aşamadan sonra, alt havzaları oluşturmak için alt havza çıkış noktaları elle belirlenmiş olup, yerleşimlerden gelen kirlilik yükleri noktasal kirlilik kaynağ1 olarak alt havzalar için tanımlanmıştır. Havzada bulunan turizm, yerleşim, restoranlardan gelen kirlilik yükleri, noktasal kirlilik yükleri olarak modelde tanımlanmıştır. Bu noktasal kaynakların modelde belirtilen sediman, azot ve fosfor ve bileşiklerinde oluşan parametreleri
“Atıksu Arıtma Tesisleri Teknik Usuller Tebliği (AATTUT, 2010)" göre hesaplanarak ve elde verisi olmayan parameterleri ise sabit parametre değerleri olarak modelde tanımlanmıştır. Yuvacık Barajı Havza Koruma ve Özel Hüküm Belirleme projesi (YBOZHP, 2014) kapsamında yapılan nüfus projeksiyon değerlendirmesine göre nüfus artışı öngörülmediğinden, noktasal kirliliğin nüfus projeksiyonuna göre değişimi dikkate alınmamıştır. Noktasal kirlilik kaynakları ve nehirlerin çıkış noktalarına göre, 63 adet toplam alt havza oluşturulmuştur (Şekil 4b). Yuvacık Barajı arazi örtüsü ve kullanımı haritası Corine 2012 verisinden elde edilmiştir. Buna göre, havzada geniş yapraklı orman alanları oldukça yoğunluktadır (Şekil 4c). Yuvacık Havzasında kahverengi orman toprakları (N tipi topraklar) geniş bir alanı kaplamaktadır (Şekil 4d). SWAT modeli toprağın fiziksel ve kimyasal özelliklerini de kullanarak havzadaki hidrolojik süreçleri hesaplamaktadır. Bu özelliklerden en 
önemli olanlar; toprağın su tutma kapasitesi, hidrolik iletkenliği, organik karbon içeriği, toprağın bünyesi (kum, kil ve çakıl içeriği) ve kalınlığıdır. Mülga Gıda, Tarım ve Hayvancılık Bakanlığı tarafindan üretilen toprak haritası (Oakes, 1958) bu özellikleri içermemektedir. $\mathrm{Bu}$ nedenle, toprak bünyesi ve özellikleri, Mülga Gıda, Tarım ve Hayvancılık Bakanlığı tarafından üretilen toprak haritası ve lejantında yer alan toprakların derinlik ve eğim bilgileri kullanılarak, Ardas ve Creutberg (1995)'in Türkiye'deki pilot alanlardaki çalışmalarına göre belirlenmiştir. Literatürde farklı toprak bünyelerinin yüzde olarak kum, silt ve kil içeriklerinin bileşimlerine göre adlandırılması, Ley vd., (1994) çalışması doğrultusunda yapılmıştır. Rosewell (1993) çalışmasına göre, USLE denklemi toprak erodibilite $(\mathrm{K})$ faktörü (USLE_K), toprak tanımlama kılavuzuna (Jahn vd., 2006) göre toprak kütle yoğunluğu (SOL_BD), su tutma kapasitesi (SOL_AWC) ve hidrolik iletkenlik değeri (SOL_K) belirlenmiştir (Çizelge 2). Yuvacık Barajı havzası eğim haritası SAM kullanılarak oluşturulmuştur (Şekil 4e). Haritada beyaz renkli alanlar eğimi yüksek olan bölgeleri göstermektedir. Havza genel olarak değerlendirildiğinde, yüksek eğimli bölgelerin yoğunlukta olduğu gözlenmektedir.

Çalışma kapsamında kullanılan model; günlük yağış, maksimum ve minimum sıcaklık, nem, güneşlenme ve rüzgar meteorolojik verilerine ihtiyaç duymaktadır. Havzada bulunan 12 istasyona ait 2006-2014 y1lları arasındaki meteorolojik verileri modele girilmiştir. SWAT modeli, iklim verilerine ait istatistiksel değerleri eksik verilerin tamamlanmasında kullanarak hidrolojik süreçleri modellemektedir. Modele girdi olarak verilen istatiksel değerler sırasıyla, aylık ortalama günlük maksimum hava sıcaklığı $\left({ }^{\circ} \mathrm{C}\right)$, aylık ortalama günlük minimum hava sıcaklığ $1\left({ }^{\circ} \mathrm{C}\right)$, bir ay içindeki günlük maksimum hava sıcaklıkları için standart sapma $\left({ }^{\circ} \mathrm{C}\right)$, bir ay içindeki günlük minimum hava sıcaklıkları için standart sapma $\left({ }^{\circ} \mathrm{C}\right)$, ortalama toplam aylık yağış $(\mathrm{mm})$, bir ayda günlük yağış için standart sapma (mm/gün), bir ay içinde günlük yağış için çarpıklık katsayısı, ayda kuru bir günü izleyen ıslak bir gün olasıllığı, ay içindeki ıslak bir günün ardından 1slak bir günün olasılığı, aylık yağış ortalama gün sayısı, aylık ortalama günlük güneş 1şınımı (MJ $/ \mathrm{m}^{2} /$ gün$)$, aylık ortalama günlük çiğlenme noktası sıcaklığ $1\left({ }^{\circ} \mathrm{C}\right)$ ve aylık ortalama günlük rüzgar hızı (m/s)'dır. Maksimum sıcaklık $19{ }^{\circ} \mathrm{C}$ ve minimum sicaklık $6{ }^{\circ} \mathrm{C}$ 'dir. Ortalama nem değerleri bölgede yaz aylarında \%60-65, k1ş aylarında ise \%70-75 değerleri arasındadır. Yıllık ortalama rüzgar hızı $1.7 \mathrm{~m} / \mathrm{sn}$, aylık ortalama buharlaşma $124.05 \mathrm{~mm}$, ortalama güneşlenme süresi yazın 8 saat, kışın ise yaklaşık 3 saattir. Aylık ortalama toplam yağış $88 \mathrm{~mm}$, maksimum aylık ortalama toplam yağış $240 \mathrm{~mm}$ ve minimum aylık ortalama toplam yağış $10 \mathrm{~mm}$ 'dir.

Havzada tarımsal alanlardan kaynaklanan kirlilik yükleri için, Kocaeli Tarım İl Müdürlüğü (2013) verilerine göre, tahil ekilen alanlarda kullanılan azotlu ve fosforlu gübre miktarları dekar başına sırasıyla, 26 ve $8.5 \mathrm{~kg}$ olarak modele tanımlanmıştır. Havzada yönetim süreçleri nadaslama, gübreleme, sulama ve hasat kaldırma olarak belirlenmiştir. Tarımsal alanlarda pek çok sayıda keson kuyu bulunmaktadır (Şekil 4b). Ancak, keson kuyulardan sulama için kullanılan su miktarı ile ilgili veri eksikliği olması nedeniyle, modelde sulamanın sı ̆ akiferden yapıldığ1 varsayılarak, ürün su stres düzeyine göre otomatik sulama seçeneği uygulanmıştır. 


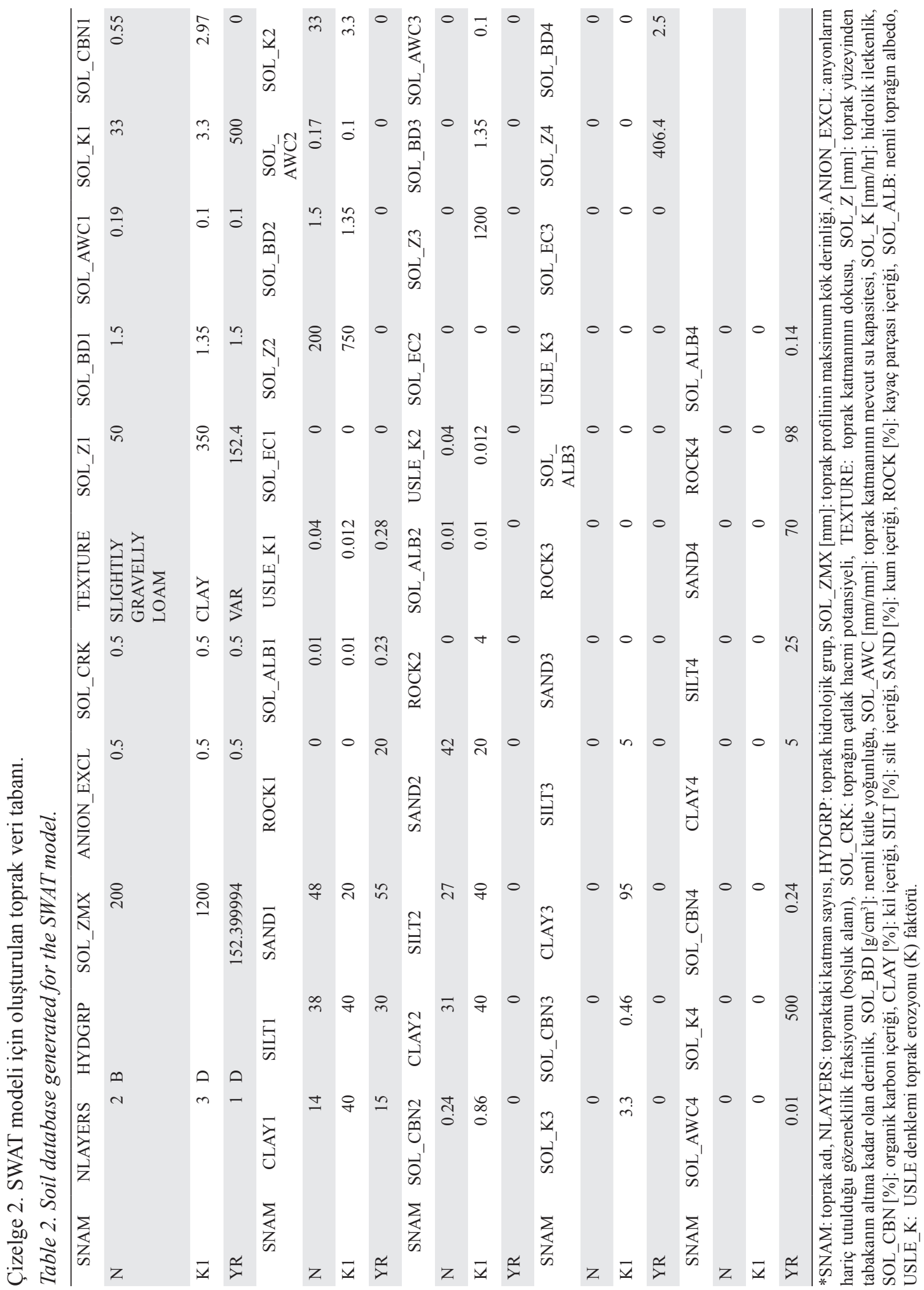




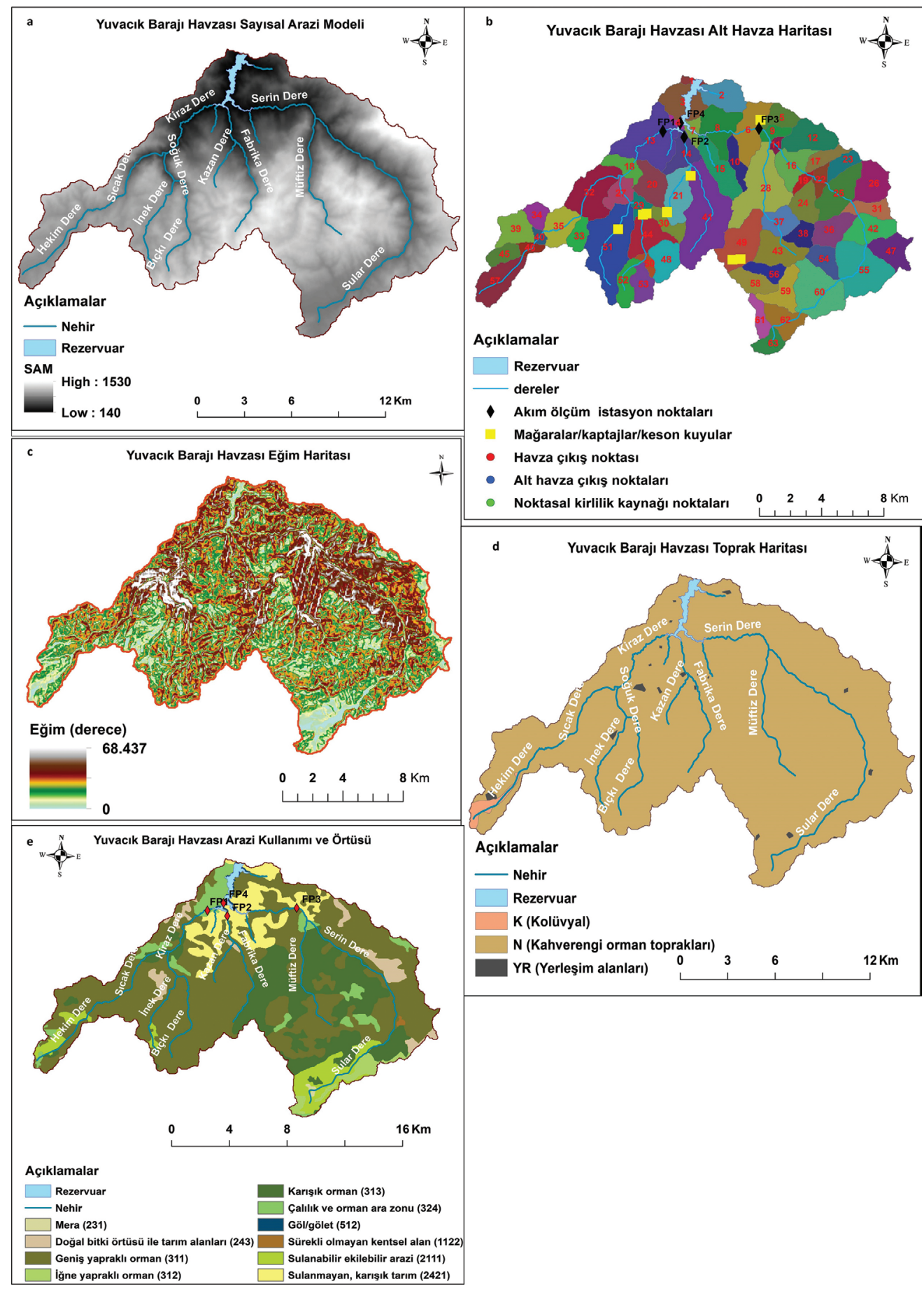

Şekil 4. a. Sayısal arazi modeli, b. Alt havza haritası, c. Eğim haritası, d. Toprak haritası e. Arazi kullanım ve örtüsü haritas1.

Figure 4. a. Digital terrain model, b. Subbasin map, c. Slope map, d. Soil map, e. Land use/cover map. 


\section{MODEL KURULUMU VE ÇALIŞTIRILMASI}

SWAT, havza içerisindeki hidrolojik süreçleri her bir alt havzada HİB kullanarak hesaplamaktadır. HİB her bir alt havzada, kullanıcı tarafindan belirlenen alansal eşik değere göre toprak, arazi kullanımı ve eğim kombinasyonundan oluşmaktadır. Bu kapsamda, çalışma alanı özellikleri dikkate alınarak, arazi kullanımı $\% 20$, toprak \%80 ve eğim \%20 eşik değerleriyle HIBB oluşturulduğunda toplam 63 alt havza için 99 HİB elde edilmiştir. İklim verileri ile birlikte toprağın fiziksel ve kimyasal parametreleri, arazi kullanım özellikleri, kirlilik kaynakları ve havzanın yönetimsel süreçleri modele tanımlandiktan sonra, modelde aylık zaman dilimi kullanılarak, 2 yıllık 1sinma periyodu sonrasinda, model 2006-2014 y1llar1 arasında çalıştırılmıştır. Yağış dağılımı için asimetrik dağılım, yüzey akışı için SCS (Soil Conservation Service) yöntemi kullanılmıştır (USDA, 1986). Sediman taşınımı için Bagnold metodu (Bagnold, 1966) uygulanmıştır. Model akım sonuçları havzada bulunan Kirazdere (FP1), Kazandere (FP2) ve Serindere (FP3) akım gözlem istasyonlarıyla, model sediman taşınım sonuçları Serindere (FP3) istasyonuyla karşılaştırılmıştır.

$\mathrm{Bu}$ çalışmada, gözlenen ve modellenen değerlerin karşılaştırılmasında, Nash-Sutcliffe Etkinlik Katsayıs1 (NSE) ve Belirleme katsayıs1 $\left(\mathrm{R}^{2}\right)$ kullanılmıştır. Belirleme katsayısı $\left(\mathrm{R}^{2}\right)$, modellenen ve gözlenen veriler arasındaki eş doğrusallık derecesini belirlemektedir. Belirleme katsayısı modellenen verinin gözlenen veri içindeki varyans oranını açıklar ve değeri 0 ile 1 arasında değişir (eşitlik 1). Daha yüksek değerler daha az hata varyansını gösterir ve tipik olarak 0.5 'ten büyük değerler yeterli olarak kabul edilir. NSE, modellenen veri varyansinin gözlenen veri varyansına kıyasla göreceli büyüklügünü belirleyen normalleştirilmiş bir istatistiktir (eşitlik 2). NSE, gözlenen ve modellenen veri grafiğinin 1:1 çizgisine ne kadar uyduğunu gösterir (Nash ve Sutcliffe, 1970).

$$
\begin{aligned}
& \mathrm{R}^{2}=\frac{\left[\sum_{\mathrm{i}}\left(\mathrm{Q}_{\mathrm{m}, \mathrm{i}}-\overline{\mathrm{Q}}_{\mathrm{m}}\right) *\left(\mathrm{Q}_{\mathrm{s}, \mathrm{i}}-\overline{\mathrm{Q}}_{\mathrm{s}}\right)\right]^{2}}{\sum_{\mathrm{i}}\left(\mathrm{Q}_{\mathrm{m}, \mathrm{i}}-\overline{\mathrm{Q}}_{\mathrm{m}}\right)^{2} * \sum_{\mathrm{i}}\left(\mathrm{Q}_{\mathrm{s}, \mathrm{i}}-\overline{\mathrm{Q}}_{\mathrm{s}}\right)^{2}} \\
& \mathrm{NSE}=1-\frac{\sum_{\mathrm{i}}\left(\mathrm{Q}_{\mathrm{m}}-\mathrm{Q}_{\mathrm{s}}\right)_{\mathrm{i}}^{2}}{\sum_{\mathrm{i}}\left(\mathrm{Q}_{\mathrm{m}, \mathrm{i}}-\overline{\mathrm{Q}}_{\mathrm{m}}\right)^{2}}
\end{aligned}
$$

$\mathrm{Q}_{\mathrm{m}, \mathrm{i}}$ - değerlendirilen bileşenin i noktasındaki gözlenen değeri;

$\overline{\mathrm{Q}}_{\mathrm{m}}$ - değerlendirilen bileşenin gözlenen değerinin ortalaması;

$\mathrm{Q}_{\mathrm{s}, \mathrm{i}}$ - değerlendirilen bileşenin i noktasındaki modellenen değeri;

$\overline{\mathrm{Q}}_{\mathrm{s}}$ - değerlendirilen bileşenin ortalama modellenen değeri.

2006 ve 2014 y1lları arasındaki FP1 istasyonundaki gözlenen aylık ortalama akım değeri $1.28 \mathrm{~m}^{3} / \mathrm{sn}$, model ile ölçülen aylık ortalama akım değeri $0.98 \mathrm{~m}^{3} / \mathrm{sn}$ ve $\mathrm{R}^{2}=0.48$, $\mathrm{NSE}=0.383$ 'dir (Şekil 5a). FP2 istasyonunda 2006-2014 y1lları arasında gözlenen aylık ortalama akım değeri $0.55 \mathrm{~m}^{3} / \mathrm{sn}$, model ile ölçülen aylık ortalama akım değeri $0.28 \mathrm{~m}^{3} / \mathrm{sn}$ ve $\mathrm{R}^{2}=0.45, \mathrm{NSE}=0.164^{\prime}$ tir. Her iki akım değerleri grafiksel olarak değerlendirildiğinde, birbirine çok benzer olmasalar da mevsimsel akım değişikliklerinin benzer olduğu gözlenmektedir (Şekil 5b). FP3 istasyonunda söz konusu yıllar için gözlenen ve modellenen aylik ortalama akım değerleri sırasıyla 1.94 ve $2.03 \mathrm{~m}^{3} / \mathrm{sn}$ ve, $\mathrm{R}^{2}=0.53$, NSE $=0.484$ 'tür (Şekil $5 \mathrm{c}$ ). FP1 ve FP3 istasyonlarında hidrolojik model ile ölçülen aylık ortalama akım değerlerinin NSE ve $\mathrm{R}^{2}$ değerleri yaklaşık olarak 0.50 değeri göstermektedir. $\mathrm{Bu}$ değer model doğruluğu açısından yeterli kabul edilirken, FP2 istasyonu için NSE ve $\mathrm{R}^{2}$ değerleri 0.50 'den küçük olduğundan model doğruluğu açısından yetersiz kabul edilmektedir (Moriasi vd., 2007) (Çizelge 3). 

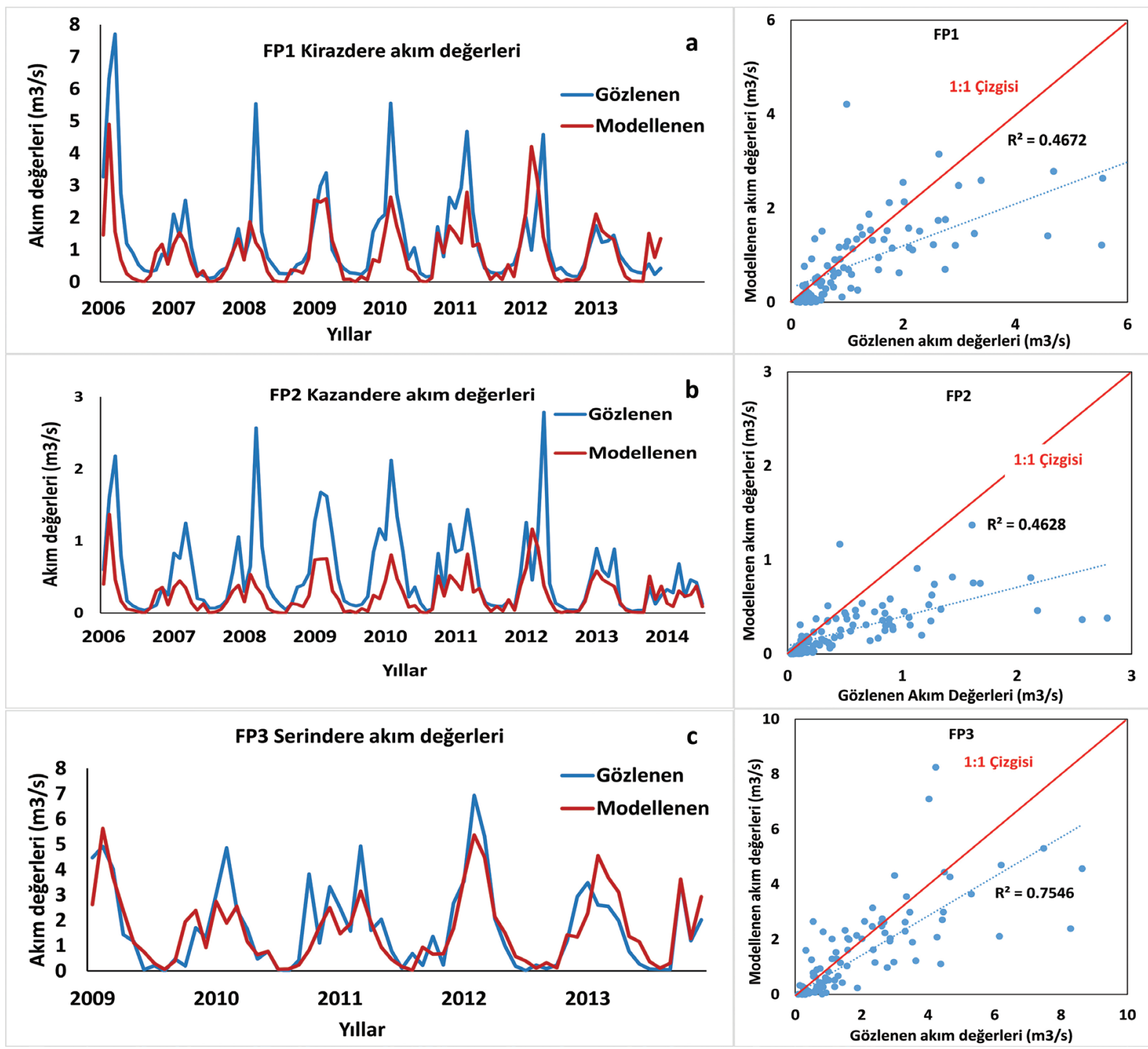

Şekil 5. Gözlenen akım değerleri ile ölçülen akım değerleri arasındaki ilişki a. FP1 Kirazdere, b. FP2 Kazandere, c. FP3 Serindere.

Figure 5. The relationship between observed and measured flow values a. FP1 Kirazdere, b. FP2 Kazandere, c. FP3 Serindere. 
Çizelge 3. Aylık zaman adımı için önerilen istatistikler için performans derecelendirmeleri (Moriasi vd., 2007).

Table 3. Performance ratings for proposed statistics for the monthly time step (Moriasi et al., 2007).

\begin{tabular}{lll}
\hline $\begin{array}{l}\text { Performans } \\
\text { derecesi }\end{array}$ & $\mathrm{R}^{2}$ & $\mathrm{NSE}$ \\
\hline Çok iyi & $0.75<\mathrm{R}^{2} \leq 1.00$ & $0.75<\mathrm{NSE} \leq 1.00$ \\
İyi & $0.65<\mathrm{R}^{2} \leq 0.75$ & $0.65<\mathrm{NSE} \leq 0.75$ \\
Yeterli & $0.5<\mathrm{R}^{2} \leq 0,65$ & $0.5<\mathrm{NSE} \leq 0.65$ \\
Yetersiz & $\mathrm{R}^{2} \leq 0.5$ & $\mathrm{NSE} \leq 0.5$ \\
\hline
\end{tabular}

\section{MODEL KALİBRASYONU}

Model kalibrasyonu, hidroloji ve sediman taşınım modelinin kullanımı için gereklidir. Model hidrolojik açıdan kalibre edildikten sonra, sediman taşınımı kalibrasyonu yapılmıştır. Model sonuçları değerlendirildiğinde, modelin doğruluğu uygulanabilirlik değerleri göstermesine rağmen (Çizelge 3), model FACT kalibrasyon metodu kullanılarak daha da iyileştirilmiştir. FACT içerisinde uygulanan optimizasyon metodu Siralı Belirsizlik Uygunluğu Algoritması (SUFI-2)'dır. Bu algoritma optimizasyonu çok sayıda parametreyi hızlı bir şekilde belirsizlik analizi ile birlikte yapabilmesi nedeniyle seçilmiştir. Yüzey akışı, baz akım, yanal akım gibi hidrolojik süreçler ile ilişkili 16 adet parametre ile 150 simulasyon sayıs1 kullanılarak kalibrasyon yapılmıştır (Çizelge 4). Model, FP1, FP2 ve FP3 akım gözlem istasyonlarındaki gözlenen akım değerleri ile karşılaştırılarak 2006-2010 yılları için kalibre, 2011-2014 yılları için valide edilmiştir. Kirazdere (FP1) istasyonunda kalibrasyon sonrasında gözlenen ve modellenen akım değerlerine göre, 2006-2010 y1llar1 arasında model gözlenen akım değerlerine göre daha düşük akım değerleri göstermektedir. Kirazdere (FP1) istasyonun ölçülen akım değerleri kalibrasyon sonrasında; 2006-2010 model sonucu $\mathrm{R}^{2}=0.48$, NSE $=0.56$ 'den $\mathrm{R}^{2}=0.73$, $\mathrm{NSE}=0.61$ 'e iyileştirilmiş olup, 2010-2014 validasyon sonucu $\mathrm{R}^{2}=0.55, \quad \mathrm{NSE}=0.50$ 'dir (Şekil 6a). Kazandere (FP2) istasyonunda modellenen akım değerleri gözlenen akım değerlerinden düşüktür. Kazandere (FP2) ölçülen akım değerleri kalibrasyon sonrasında; 20062010 model sonucu $\mathrm{R}^{2}=0.60$, $\mathrm{NSE}=0.12$ 'den $\mathrm{R}^{2}=0.76$, NSE $=0.45$ 'e iyileştirilmiş olup, 20102014 validasyon sonucu $\mathrm{R}^{2}=0.62, \mathrm{NSE}=0.50$ ' dir (Şekil 6b). Serindere (FP3) istasyonunda ölçülen akım değerleri kalibrasyon sonrasında; 20062010 model sonucu $\mathrm{R}^{2}=0.60$, NSE $=0.48$ 'den $\mathrm{R}^{2}=0.69$, NSE $=0.64$ 'e iyileştirilmiş olup, 20102014 validasyon sonucu $\mathrm{R}^{2}=0.69$, NSE $=0.68$ 'dir. Serindere (FP3) istasyonunda ölçülen akım değerleri gözlenen akım değerleriyle karşılaştırıldığında, kalibrasyon ve validasyon süreçleri sonrasında diğer iki istasyona göre en iyi model sonucunu vermektedir (Şekil 6c, 7).

Model aynı zamanda 200 simulasyon sayıs1 ile FACT kullanılarak, 2010-2014 y1llar1 için sediman taşınımı kalibrasyonu yapılmıştır. Sediman taşınımında önemli etkileri olduğu düşünülen yanal, baz akım, erozyon süreçleri için, kanal hidrolik iletkenlik değeri, Manning katsayısı, aşındırma faktörü vb. parametreler kalibrasyon sürecinde kullanılmıştır (Çizelge 5). 
Çizelge 4. Hidrolojik süreçler için kalibrasyon parametreleri.

Table 4. Calibration parameters for hydrological processes.

\begin{tabular}{|c|c|c|c|c|}
\hline Parametreler & Açıklama & Min-Max & Model & Kalibrasyon \\
\hline r__CN2.mgt & $\begin{array}{c}\text { İlk SCS akış eğrisi numarası (ortalama } \\
\text { değer) }\end{array}$ & $-0.2-0.2$ & 72.16 & 74.44 \\
\hline r_SOL_AWC().sol & Toprak tabakasının mevcut su kapasitesi & $-0.2-0.1$ & 0.19 & 0.22 \\
\hline r_sOL_K().sol & Doymuş hidrolik iletkenlik (mm/saat) & $-0.8-0.8$ & 16.5 & 14.14 \\
\hline r_SOL_BD().sol & Nemli kütle yoğunluğu $\left(\mathrm{Mg} / \mathrm{m}^{3}\right.$ veya $\left.\mathrm{g} / \mathrm{cm}^{3}\right)$ & $-0.5-0.6$ & 1.5 & 2.28 \\
\hline a_GWQMN.gw & $\begin{array}{l}\text { Geri dönüşün gerçekleşmesi için gereken } \\
\text { sığ akiferdeki su eşik derinliği }\left(\mathrm{mm} \mathrm{H}_{2} 0\right)\end{array}$ & $0-25$ & 1000 & 1019.49 \\
\hline a_GW_REVAP.gw & Yeraltı suyu "revap" katsayıs1 & $-0.1-0$ & 0.02 & 0.02 \\
\hline v_REVAPMN.gw & $\begin{array}{l}\text { Siğ akiferdeki "derinleşme” ya da oluşacak } \\
\text { derin akiferin süzülmesi için su derinliğinde } \\
\text { eşik derinliği }\left(\mathrm{mm} \mathrm{H}_{2} \mathrm{O}\right)\end{array}$ & $0-500$ & 750 & 440.29 \\
\hline v_ALPHA_BF.gw & Baz akım alfa katsayısı & $0-1$ & 0.48 & 0.78 \\
\hline v_GW_DELAY.gw & Yeraltı suyu gecikme süresi (gün) & $30-450$ & 31 & 140.95 \\
\hline v_ESCO.hru & Toprak evapotranspirasyon faktörü & $0.8-1$ & 0.95 & 0.81 \\
\hline v__SFTMP.bsn & Kar yağışı sıcaklığ $1\left({ }^{\circ} \mathrm{C}\right)$ & $-5.0-5.0$ & 1 & 1.37 \\
\hline v__SMTMP.bsn & Kar erimesi taban sıcaklığ $\left({ }^{\circ} \mathrm{C}\right)$ & $-5.0-5.0$ & 0.5 & 6.12 \\
\hline v__SMFMX.bsn & $\begin{array}{l}21 \text { Haziran'da kar için erime faktörü } \\
\qquad\left(\mathrm{mm} \mathrm{H}_{2} \mathrm{O} / \text { gün }\right)\end{array}$ & $1.7-6.5$ & 4.5 & 3.90 \\
\hline v__SMFMN.bsn & $\begin{array}{l}21 \text { Aralık'ta kar için erime faktörü } \\
\qquad\left(\mathrm{mm} \mathrm{H}_{2} \mathrm{O} / \text { gün }\right)\end{array}$ & $1.7-6.5$ & 4.5 & 2.93 \\
\hline v__TIMP.bsn & kar paketi gecikme faktörü & $0.01-1$ & 1 & 0.05 \\
\hline v $\quad$ SURLAG.bsn & yüzeysel akış gecikme katsayısı & $0.05-24$ & 4 & 10.26 \\
\hline
\end{tabular}



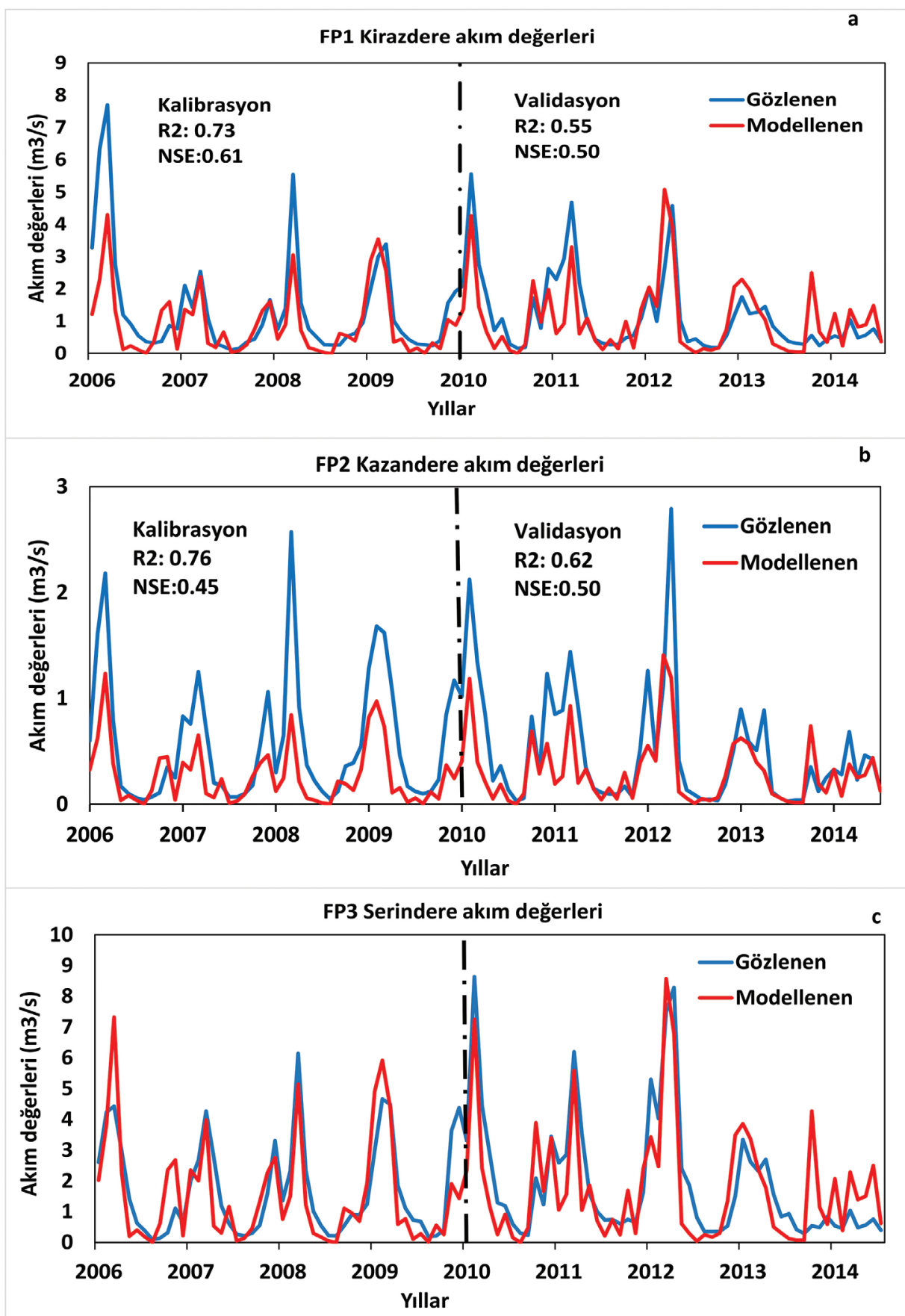

Şekil 6. Kalibrasyon sonrasında ölçülen ve gözlenen akım değerleri arasındaki ilişkiyi gösterir grafik a. FP1 Kirazdere, b. FP2 Kazandere, c. FP3 Serindere.

Figure 6. The relationship between observed and measured flow values after calibration a. FP1 Kirazdere, b. FP2 Kazandere, c. FP3 Serindere. 
Çizelge 5. Sediman taşınımı için kalibrasyon parametreleri.

Table 5. Calibration parameters for the sediment transportation.

\begin{tabular}{|c|c|c|c|c|}
\hline Parametre & Açıklama & Min-max & Model & Kalibrasyon \\
\hline v_USLE_P.mgt & USLE denklemi destek uygulama faktörü & $0-1$ & 0.97 & 0.136 \\
\hline v_OV_N.hru & Karadan akış için Manning "n" değeri & $0.01-30$ & 0.010 & 17.98 \\
\hline $\mathrm{V}$ CH_K2.rte & Kanal hidrolik iletkenlik değeri & $0-500$ & 0 & 211.07 \\
\hline $\mathrm{v}$ _CH_N2.rte & Ana dere için Manning " $n$ " değeri & $0-0.30$ & 0.014 & 0.13 \\
\hline $\mathrm{v}$ SURLAG.bsn & Yüzeysel akış gecikme katsayısı & $1-24$ & 10.26 & 5.17 \\
\hline v__PRF.bsn & $\begin{array}{l}\text { Ana kanalda sediment yönlendirme için tepe hızı } \\
\text { ayar faktörü }\end{array}$ & $0-1$ & 1 & 0.43 \\
\hline$v_{\text {___SPCON.bsn }}$ & $\begin{array}{l}\text { Kanal sedimenti yönlendirmesi sırasında yeniden } \\
\text { sürüklenebilecek maksimum sediment miktarını } \\
\text { hesaplamak için doğrusal parametre }\end{array}$ & $0-0.001$ & 0.0001 & 0.005 \\
\hline $\mathrm{v}_{\text {__SPEXP.bsn }}$ & $\begin{array}{l}\text { Kanal sediment yönlendirmesinde sürüklenen } \\
\text { tortu hesaplamak için exponent parametresi }\end{array}$ & $1-1.5$ & 1 & 1.46 \\
\hline $\mathrm{r} \quad$ SLSUBBSN.hru & Ortalama eğim uzunluğu & $-0.5-0.5$ & 60.976 & 21.272 \\
\hline $\mathrm{V} \_\mathrm{CH}$ _COV1.rte & Kanal aşındırma faktörü & $-0.05-0.6$ & 0 & 0.81 \\
\hline $\mathrm{V} \_\mathrm{CH}$ _COV2.rte & Kanal örtü faktörü & $-0.001-1$ & 0 & 0.32 \\
\hline v_ALPHA_BNK.rte & Akarsudaki baz akım için Alfa faktörü & $0-1$ & 0 & 0.75 \\
\hline v_LAT_SED.hru & $\begin{array}{l}\text { Yanal akış ve yeraltı suyu akışında tortu } \\
\text { konsantrasyonu }\end{array}$ & $0-5000$ & 0.0 & 1669.17 \\
\hline $\mathrm{v} \_\mathrm{CH}$ _K1.sub & $\begin{array}{l}\text { Akarsu kolu kanalı alüvyonunda etkin hidrolik } \\
\text { iletkenlik }\end{array}$ & $0-300$ & 0.0 & 286.79 \\
\hline $\mathrm{V} \_\mathrm{CH}$ _N1.sub & Akarsu kolu kanalı için Manning'in N değeri & $0.01-30$ & 0.014 & 14.46 \\
\hline $\mathrm{v} \_\mathrm{CH}$ _D50.bsn & Ana kanal yatağının medyan parçacık çapı $(\mathrm{mm})$ & $10-100$ & 50 & 65.56 \\
\hline
\end{tabular}

Kalibrasyon sonrasinda, Serindere istasyonunda modellenen ve gözlenen sediman miktarı karşılaştırıldığında, gözlenen ve modellenen değerler birbirine yakın olmasına rağmen, 2012 yılında gözlenen miktar modellenen miktara göre daha fazladır (Şekil 8). Kalibrasyon sonucunda model $\mathrm{R}^{2}=0.60$, $\mathrm{NSE}=0.59$ değerleri ile iyileştirilmiștir. Sediman miktarının arazide ölçümlerinde çok fazla hata ve belirsizlik içermesi nedeniyle, sediman taşınım model kalibrasyonu sürecinde model doğruluğunu kabul edilebilir değerlere yaklaştırabilmek oldukça zordur. Bu çalışmada, Serindere istasyonunun ilişkili olduğu alt havzalardaki morfoloji diğer iki istasyonun ilişkili olduğu alt havzaların morfolojisine göre daha az değişkenlik göstermektedir. Ayrıca,
Kirazdere ve Kazandere istasyonlarının ilişkili olduğu alt havzalarda tarımsal faaliyetler diğer alt havzalara göre daha yoğundur, bu bölgelerde mağaralar ve keson kuyular bulunmaktadır. Tarımsal alanlardaki sulama miktarlarıyla ilgili veri eksikliği, mağaralardaki su kaybı ve keson kuyulardan kullanılan su miktarıyla ilgili eksik veriler, Kirazdere ve Kazandere akım ve sediman model sonuçlarını olumsuz yönde etkilemektedir. Serindere bölgesindeki daha az değişkenlik gösteren havza özellikleri ve tarımsal alanların diğer alt havzalara göre az olması, model belirsizliğini azaltarak akım ve sediman model sonuçlarının diğer iki istasyona göre daha iyi olmasına neden olmaktadır. Bu nedenle, sadece Serindere sediman gözlemleri kullanılarak sediman taşınım modellemesi yapılmıştır. 

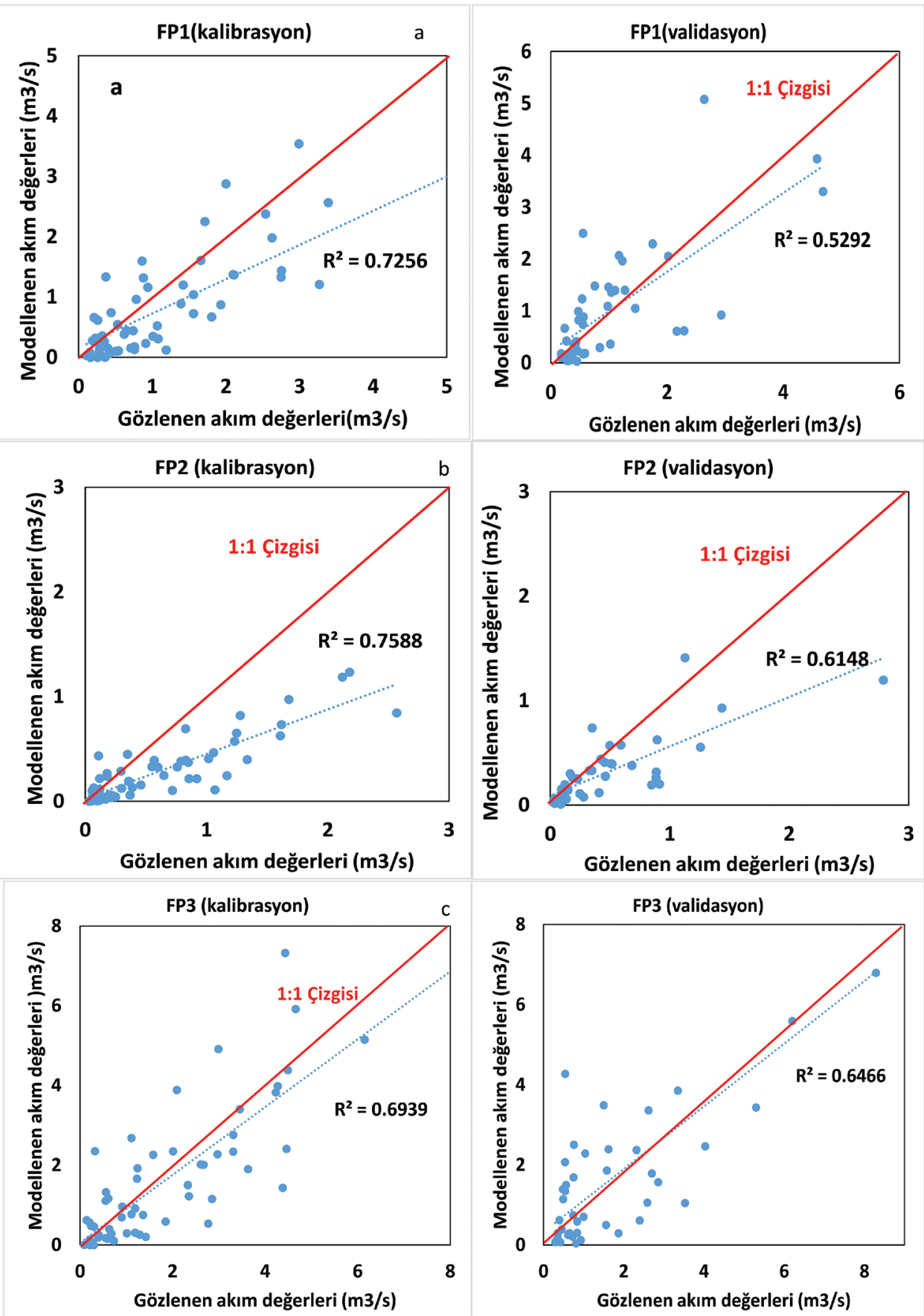

Şekil 7. Kalibrasyon ve validasyon periyodları için saçılım grafikleri a. Kirazdere (FP1), b. Kazandere (FP2), c. Serindere (FP3).

Figure 7. Scatter plots for calibration and validation periods a. Kirazdere (FP1), b. Kazandere (FP2), c. Serindere (FP3). 


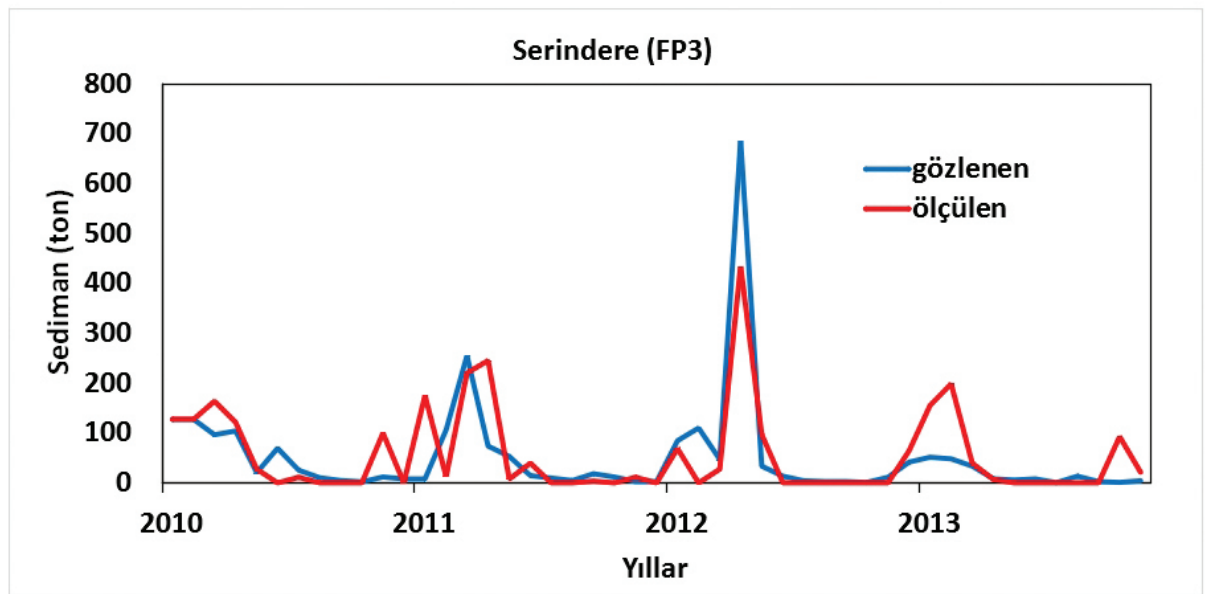

Şekil 8. Serindere kalibrasyon sonrasında ölçülen ve hesaplanan sediman miktarı arasındaki ilişki.

Figure 8. The relationship between observed and measured sediment amount at Serindere river after calibration.

\section{İKLIM DEĞİŞiKLLIĞí ETKİsi}

Meteoroloji Genel Müdürlüğü iklim değişikliğinin gelecekte ülkemize nasıl etkileyeceğini ortaya koyabilmek için, 20162099 dönemi için HadGEM2-ES, MPI-ESMMR, GFDL-ESM2M küresel model veri setlerini kullanarak iklim projeksiyonları geliştirmiştir. $\mathrm{Bu}$ çalışmada, küresel model veri setleri RegCM4.3.4 bölgesel modeli ile dinamik ölçek küçültme yöntemiyle, RCP 4.5 ve RCP 8.5 senaryolarına göre, 1971-2000 referans periyotlu 2016-2040, 2041-2070, 2071-2099 gelecek periyotlu $20 \mathrm{~km}$ çözünürlüklü projeksiyon sonuçları elde edilmiştir. Yuvacık Havzası'nda iklim değişikliğinin akım ve sediman taşınıma etkilerini ortaya koyabilmek maksadiyla, Meteoroloji Genel Müdürlüğü’nün söz konusu çalışma sonucunda elde edilen iklim projesiyon verileri kullanılmıştır.

Hükümetler Arası İklim Değişikliği Paneli'nin Beşinci Değerlendirme Raporuna (IPCC, 2014) göre Temsilci Konsantrasyon Yolları (RCPs: Representative Concentration Pathways), küresel sera gazı ve aerosol konsantrasyonları ile alternatif gelecek senaryoları (SRES) başlangıç olarak kabul eden yeni senaryolardır. 2100 y1lına kadar toplam 1şınımsal zorlama yoluna ve seviyesine bağlı olarak, 2.5, 4.5, 6.0 ve 8.5 olarak tanımlanan dört RCP vardır. Bu çalışmada, RCP 4.5 (540 ppm $\mathrm{CO}_{2}$ ) ve $\mathrm{RCP} 8.5$ (940 ppm $\mathrm{CO}_{2}$ ) senaryoları gelecekteki iklim projeksiyonlarının Yuvacık Barajı Havzasına etkilerini ortaya koymak için seçilmiştir. RCP 4.5, geniş ölçüde önceden tanımlanmış zorlama stabilizasyon kısıtlamaları ile orta düzeyde sera gazı konsantrasyonlarının uzun vadeli seviyesini varsayarken, RCP 8.5, sera gazı emisyonlarının 21. yüzyılda zamanla artacağını ve 2100 yılına kadar çok yüksek seviyelere yaklaşacağını kabul etmektedir (IPCC, 2014). RCP 4.5 ve RCP 8.5 senaryolarına göre, 2021-2099 yılları için tahmin edilen aylık ortalama toplam yağış ve ortalama sıcaklıkta meydana gelebilecek değişiklikler, havzada bulunan 12 meteoroloji istasyonun 2006-2014 yılları arasındaki ölçümleriyle karşılaştırılmıştır (Şekil 9a). 2021-2099 yılları arasında aylık ortalama yağış toplamı miktarlarında düşüş tahmin edilmiştir. 2006-2014 yılları arasında y1l 
içinde Ekim, Aralık ve Haziran aylarında daha fazla yağış ölçülmesine rağmen, 2021-2099 yıllarında en fazla yağış yağması beklenen aylar Nisan ve Ağustos aylarıdır. 2021-2099 yıllar1 arasında aylık ortalama sicaklıklarda, 2006-2014 yıllarına göre RCP 8.5 senaryosuna göre yaklaşı $0.03{ }^{\circ} \mathrm{C}$ 'lik bir artış olması beklenirken RCP 4.5 senaryosunda göre $1.24{ }^{\circ} \mathrm{C}$ 'lik azalma tahmin edilmiştir (Şekil 9b).
Hidrolojik model 2021-2099 y1lları arasında RCP 4.5 ve RCP 8.5 senaryolarına göre çalıştırılarak, bu yıllar arasındaki iklim değişikliğinin su miktarı ve sediman taşınımına etkisi ortaya konulmaya çalışılmıştır. RCP 8.5 ve RCP 4.5 senaryolarına göre, sirasiyla ortalama akım değerleri; Serindere'de 0.86 ve $0.68 \mathrm{~m}^{3} / \mathrm{s}$, Kazandere'de 0.17 ve $0.14 \mathrm{~m}^{3} / \mathrm{s}$, Kirazdere'de 0.41 ve $0.33 \mathrm{~m}^{3} / \mathrm{s}$ olarak tahmin edilmiştir. $\mathrm{Bu}$ değerler, 2006-2014 yıllarına ait ölçülen akım değerleri ile karşılaştırıldığında; RCP 8.5 ve RCP 4.5 senaryolarına göre sirasıyla, Kirazdere'de

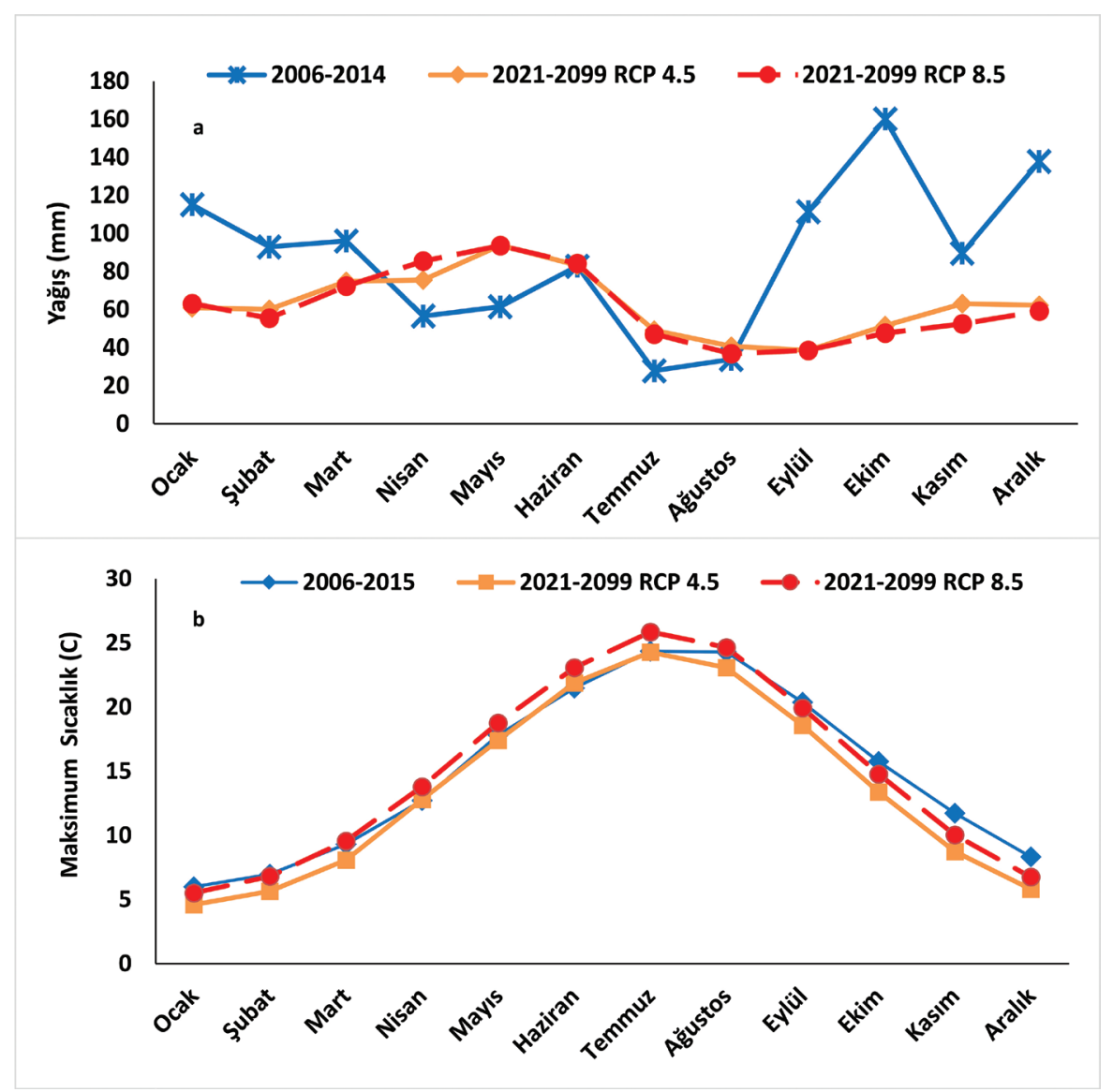

Şekil 9. a. 2021-2099 dönemi için tahmin edilen ve 2006-2015 dönemi için gözlenen aylık ortalama toplam yağış, b. 2021-2099 dönemi için tahmin edilen ve 2006-2015 dönemi için gözlenen aylık ortalama sıcaklık.

Figure 9. a. Monthly average total precipitation estimated for 2021-2099 period and observed for 2006-2015 period, b. Monthly average temperature estimated for 2021-2099 period and observed for 2006-2015 period. 
1.68 ve $1.76 \mathrm{~m}^{3} / \mathrm{s}$, Serindere'de 1.23 ve 1.41 $\mathrm{m}^{3} / \mathrm{s}$, Kazandere'de 0.36 ve $0.39 \mathrm{~m}^{3} / \mathrm{s}$ azalma gözlenmektedir. Serindere'de 2021-2040 yılları arasında azalan yağış miktarına bağlı olarak akım değerlerinde düşme, 2040-2045 yıllarında artan yağış miktarına bağlı olarak akım değerlerinde artış tahmin edilmektedir. Kirazdere ve Kazandere'de 2021-2040 ve 2090-2099 y1lları arasında tahmin edilen yağış miktarı diğer yıllara göre düşüktür, bu nedenle bu yıllarda akım debilerinde azalma tahmin edilmektedir. Ayrıca, özellikle Kazandere ve Kirazdere'de modellenen yıllar için pik akım değerlerinde yaklaşık $8 \mathrm{~m}^{3 /}$ s'den $2 \mathrm{~m}^{3} / \mathrm{s}$ 'ye ciddi miktarlarda azalma olduğu görülmektedir. 2021-2040 yılları arasında tahmin edilen yağış miktarlarının azalması ve sıcaklık değerlerinin artması, 2021-2040 yılları arasında akım debilerinde 2006-2014 yılları debileri ile karşılaştırıldığında azalmaya neden olmaktadır (Şekil 10).

Serindere istasyonunda 2010-2014 y1llar1 için gözlenen aylık ortalama 49 ton sediman miktarı 2021-2099 yılları için RCP 4.5 ve RCP 8.5 senaryolarına göre sirasıyla, aylık ortalama 247.58 ve 332.22 ton olarak tahmin edilmektedir (Şekil 11). Nisan ve Ağustos aylarında tahmin edilen yağış miktarlarında ve sıcaklık değerlerinde artış havzada mekanik erozyon oluşumuna neden olacak, böylece akımla taşınan sediman miktarında artış, meydana gelecektir.

\section{KENTSEL SU KULLANIMI VE ÇEVRE ÜZERINDEKI MUHTEMEL ETKİ VE ÖNERILER}

İklim değişikliğinin RCP 4.5 ve RCP 8.5 senaryolarına göre yağış ve sıcaklık üzerine etkileri incelendiğinde (Şekil 9), her iki senaryo için ortalama aylık yağış toplamı miktarlarında azalma, RCP 4.5 senaryosuna göre aylı ortalama sicaklıkların azalması beklenirken, RCP 8.5 senaryosuna göre artış gözlenmektedir. $\mathrm{Bu}$ etkilerin doğal sonucu olarak, Yuvacık
Baraj gölünü besleyen derelerin debilerinde azalma meydana gelmesi tahmin edilmektedir. Kirazdere ve Serindere akım debilerinde Kazandere ile karşılaştırıldığında, çok daha fazla azalma beklenmektedir. Kirazdere ve Serindere havza morfolojisi ve hidrolojisi açısından, Kazandere'ye göre farklılık göstermektedir. Kazandere'nin ölçüm yaptığı istasyonun ilişkili olduğu alt havza diğer iki istasyonun ilişkili olduğu havzalara göre daha küçük olduğundan, gecikme zamanı azalacaktır. $\mathrm{Bu}$ nedenle, iklim değişikliliğinin akım debilerine etkisi farklıdır. Havza içerisinde alt havzalarda değişen hidrolojik, morfolojik, arazi kullanımı, bitki örtüsü, fiziksel vb. özelliklerin iklim değişikliğinin akım debilerine olan etkilerinde farkl11ıklar göstereceği için, su yönetimi açısından her bir alt havza ayrı ayrı planlanmalıdır. Yuvacık Barajını besleyen derelerin debi değerlerinde meydana gelmesi muhtemel önemli miktardaki düşüş, baraj gölünde su hacminde azalmaya sebep olacaktır. $\mathrm{Bu}$ nedenle, baraj gölünden sulama yapılan tarım alanlarındaki mahsullerin fonolojik döngüsü dikkate alınarak detaylı bir analiz yapılmalıdır. Tarım İl Müdürlüğü, iklim değişikliğinin etkilerini dikkate alarak havzada ürün deseni planlaması yapmalıdır. Kocaeli Büyükşehir Belediyesi ve Devlet Su İşleri sulama yapilan alanlarla ilgili kuraklık eylem planlarını hazırlamalıdır. 2021-2099 yıllarında sediman taşınımı miktarı tahminleri dikkate alındığında sediman taşınım miktarında RCP 4.5 ve RCP 8.5 senaryolarına göre artış gözlenmiştir (Şekil 11). Ayrıca, kuraklık havzadaki orman alanlarının azalmasına sebebiyet vererek toprak erozyonun artmasina zemin hazırlayacaktır. Buna bağlı olarak, baraj gölüne sediman taşınımı artacağından baraj gölünün kullanım süresi azalacaktır. Havzadaki nehir akım debilerinde ve sediman miktarındaki değişikliklikler çevresel akışı olumsuz yönde etkileyeceğinden havzada ekolojik dengenin korunmasına yönelik çalışmalar yapılmalıdır. 

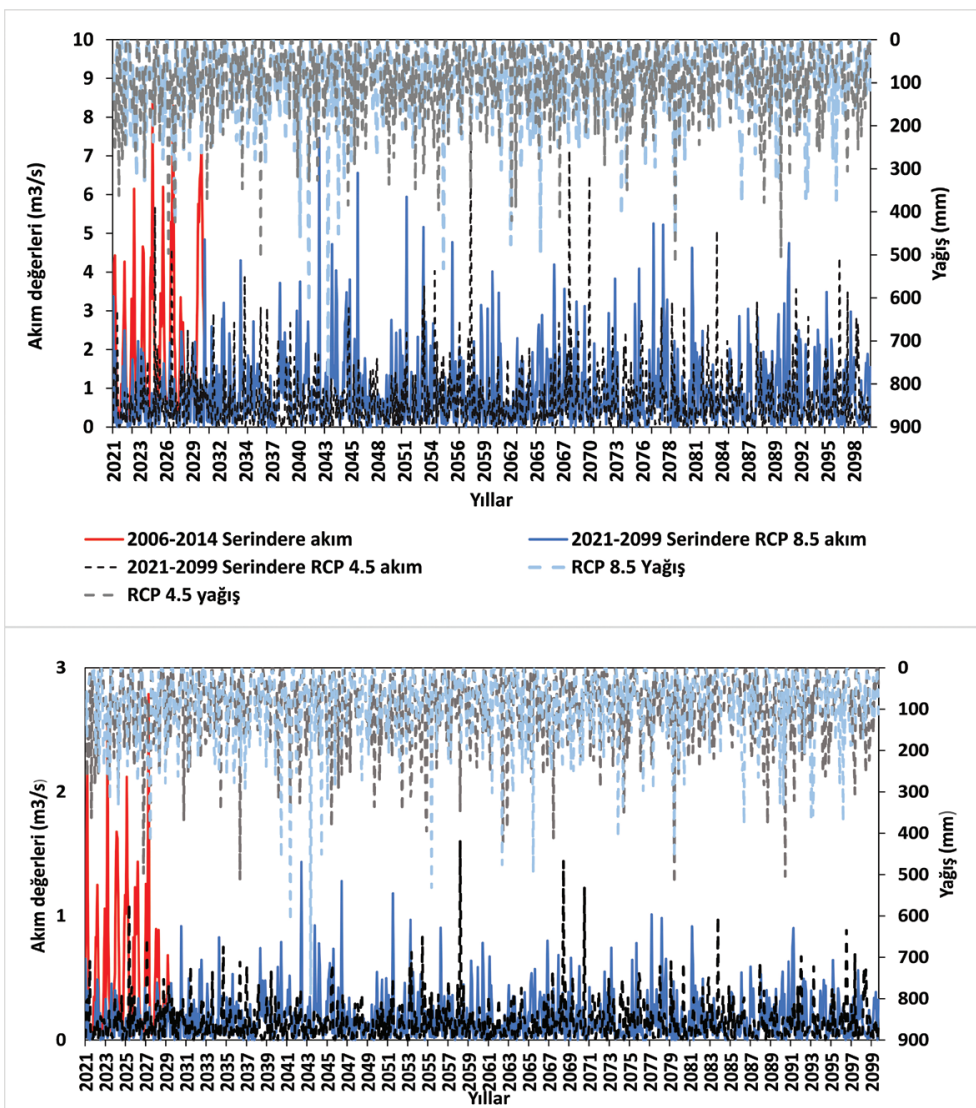

$$
\begin{array}{ll}
\text { - 2006-2014 Kazandere akım } & \text { 2021-2099 Kazandere RCP 8.5 akım } \\
\text { - - 2021-2099 Kazandere RCP 4.5 akım } & \text { - - RCP 4.5 Yağıs } \\
\text { - - RCP 8.5 Yağıs } &
\end{array}
$$
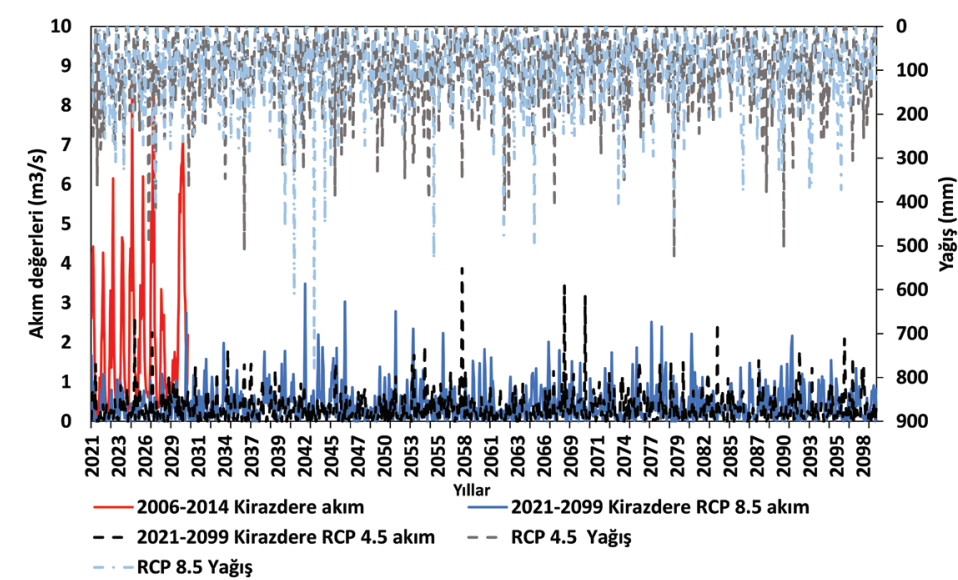

Şekil 10. 2021-2099 yılları için RCP 4.5 ve RCP 8.5 senaryolarına göre tahmini akım değerleri a. Kirazdere, b. Serindere, c. Kazandere.

Figure 10. Estimated flow values based on RCP 4.5 and RCP 8.5 scenarios for 2021-2099 period a. Kirazdere, $b$. Serindere, c. Kazandere. 


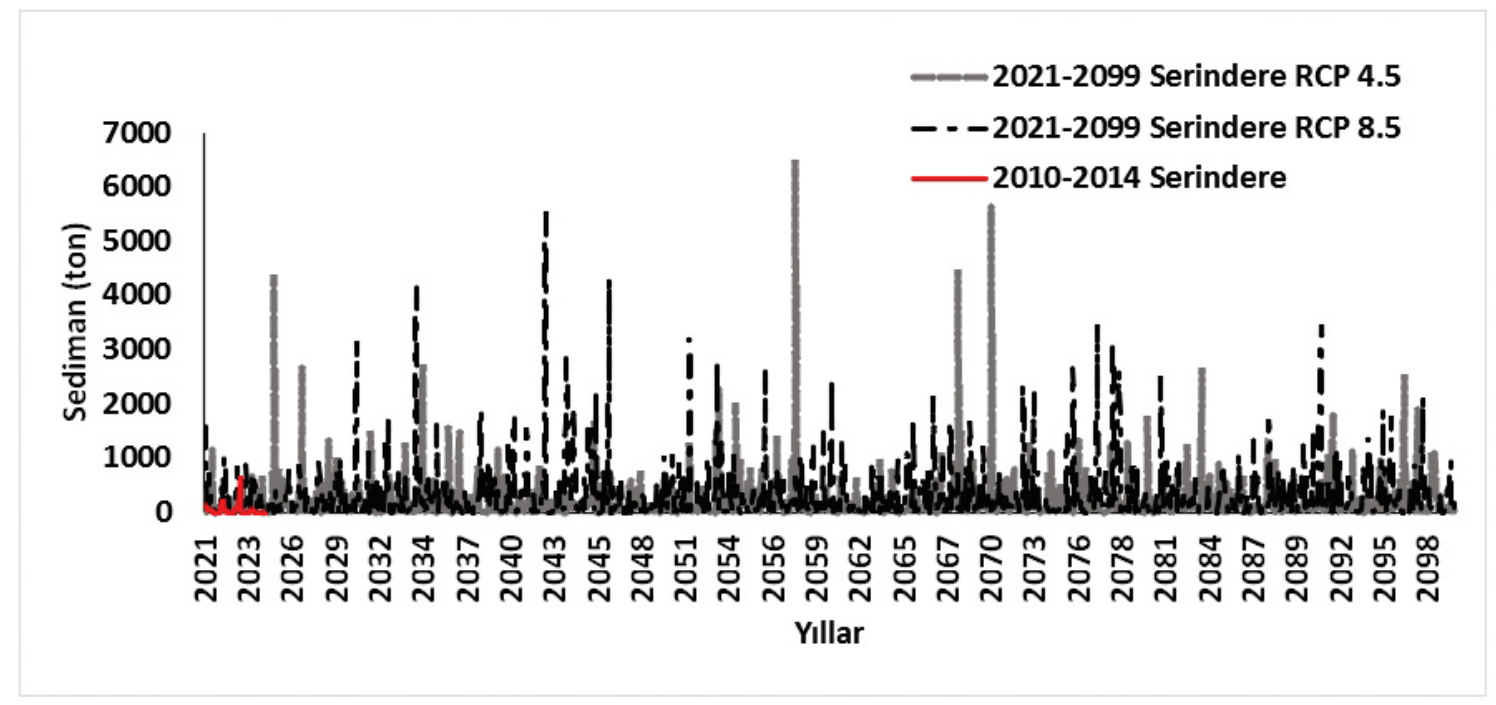

Şekil 11. Serindere, 2021-2099 yılları için RCP 4.5 ve RCP 8.5 senaryosuna göre tahmini sediman değerleri.

Figure 11. Estimated sediment values of Serindere based on RCP 4.5 and RCP 8.5 scenario for 2021-2099.

Havzadaki sulama ve içme suyu ihtiyacının söz konusu etkiler doğrultusunda giderilmesine yönelik, ek önlem çalışmalarına başlanılması önem arz etmektedir. Yakın dönem (2021-2040) y1lları için su yönetim planlama faaliyetleri yürütülmesi için, havzada su yönetimiyle ilgili kurum kuruluşlarının uzmanlarından oluşan çalışma grubu oluşturulmalıdır. Çalışma grubunu üyelerinin farklı meslek gruplarından oluşması, bütüncül anlayışla havza yönetim planlaması yapılabilmesi için önemlidir. Böylece, havzada sürdürülebilir arazi ve su yönetimi sağlanmış olacaktır.

\section{SONUÇ VE ÖNERILER}

Yuvacık Baraj1 Sakarya ve İzmit illerinin içme suyu ihtiyacını karşılamak, sulama, sel ve taşkın önleme ve kuraklık dönemlerinde su yönetimi sağlamak üzere kullanılmaktadır. $\mathrm{Bu}$ nedenle, iklim değişikliğinin havzada su ve sediment miktarına olan etkileri tahmin edilerek, barajdan elde edilen suyun yönetiminin ve planlamasının yapılması için zemin hazırlanmıştır. $\mathrm{Bu}$ kapsamda, Meteoroloji Genel Müdürlüğü tarafindan RCP 4.5 ve RCP 8.5 senaryolarına göre üretilen veriler hidrojik modelde kullanilarak, 2021-2099 y1llar1 arasındaki iklim değişikliğinin su ve sediment miktarına olan etkileri tahmin edilmiştir. Yuvacık Barajı'n1 besleyen Kazandere, Kirazdere ve Serindere derelerinin 2006-2014 yıllarında ölçülen aylık ortalama akım değerleri sırasıyla, $0.55,1.28$ ve $1.94 \mathrm{~m}^{3} / \mathrm{s}$ 'dir. RCP 4.5 ve RCP 8.5 senaryolarına göre, 2021-2099 yılları için sirasiyla Kazandere 0.14 ve $0.17 \mathrm{~m}^{3} / \mathrm{s}$, Kirazdere 0.41 ve $0.33 \mathrm{~m}^{3} / \mathrm{s}$, Serindere 0.86 ve $0.68 \mathrm{~m}^{3} / \mathrm{s}$ tahmin edilmiş olup, bu değerler barajı besleyen derelerin akım debilerinde azalma olacağına işaret etmektedir. Serindere istasyonunda 20102014 yılları için ölçülen yaklaşık aylık ortalama 49 ton sediman miktarı 2021-2099 yılları için RCP 4.5 senaryosuna göre aylık ortalama 247.58 ton ve RCP 8.5 senaryosuna göre 332.21 ton 
olarak hesaplanmıştır. Baraj gölünü besleyen derelerin debi değerlerindeki azalma, baraj gölünün su hacminde azalmaya neden olacaktır. $\mathrm{Bu}$ nedenle, baraj gölünden sulanan alanlardaki ürün deseni ve içme suyu kullanımı için geleceğe yönelik su yönetim planlaması yapılması gerekmektedir. Ayrıca, debi miktarlarında düşme havzadaki orman alanlarının azalmasına, bu durumun sonucunda da erozyon miktarında artış meydana gelecektir. Böylece, baraj gölüne gelen sediman miktarı artacağından baraj gölünün kullanım süresi kısalacaktır.

\section{KATKI BELIRTME}

Yuvacık Baraj1 Havza Koruma ve Özel Hüküm Belirleme Projesi kapsamında birlikte çalıştığım Kocaeli Büyükşehir Belediyesi çalışanları Jeoloji Yüksek Mühendisi Abdullah Altuntaş ve Harita Mühendisi Azize Koç'a özverili çalışmaları ve destekleri için en derin saygı ve teşekkürlerimi sunarım. Ayrıca, arazi çalışmaları ve veri konusunda desteklerinden ötürü Kocaeli Büyükşehir Belediyesi ISU Genel Müdürlüğü’ne saygılarımı sunarım.

\section{KAYNAKLAR}

Alp, E., Özcan, Z., 2017. Effects of climate change on diffuse pollution in Lake Mogan Watershed. American Geophysical Union, Fall Meeting 2017.

Ardas, S., Creutzberg, D., 1995. Soil Reference Profiles of Turkey. Dept. of Soil ScienceFaculty of Agriculture-Çukurova University, International Soil Reference and Information Centre, Country Report 3.

Arnold, J.G., Srinivasan, R., Muttiah, R.S., Williams, J.R., 1998. Large area hydrologic modeling and assessment part I: model development. Journal of the American Water Resources Association, 34 (1), 73-89.
Arnell, N.W., Brown, S., Gosling, S.N., Gottschalk, P., Hinkel, J., Huntingford, C., Lloyd-Hughes, B., Lowe, J.A., Nicholls, R.J., Osborn, T.J., Osborne, T.M., Rose, G.A., Smith, P., Wheeler, T.R., Zelazowski, P., 2014. The impacts of climate change across the globe: A multi-sectoral assessment. Climatic Change, 134, 457-474. doi:10.1007/s10584-014-1281-2.

Ahn, S. R., Jeong, J. H., Kim, S. J., 2016. Assessing drought threats to agricultural water supplies under climate change by combining the SWAT and MODSIM models for the Geum River basin, South Korea. Hydrological Sciences Journal, 61(15), 2740-2753. doi:10.1080/02626667.201 5.1112905 .

AATTUT, 2010. Atıksu Arıtma Tesisleri Teknik Usuller Tebliği. Resmi Gazete, 27527.

Bagnold, 1966. An Approach to the Sediment Transport Problem From General Physics. Geological Survey Professional Paper, 422-I.

Bhatta, B., Shrestha, S., Shrestha, P. K., Talchabhadel, R., 2019. Evaluation and application of a SWAT model to assess the climate change impact on the hydrology of the Himalayan River Basin. CATENA, 181, 104082. doi:10.1016/j. catena.2019.104082.

Bucak, T., Trolle, D., Tavşanoğlu, Ü. N., Çakıroğlu, A. İ., Özen, A., Jeppesen, E., Beklioğlu, M., 2018. Modeling the effects of climatic and land use changes on phytoplankton and water quality of the largest Turkish freshwater lake: Lake Beyşehir. Science of The Total Environment, 621, 802-816.

Chaemiso, S.E., Abebe, A., Pingale, S.M., 2016. Assessment of the impact of climate change on surface hydrological processes using SWAT: a case study of Omo-Gibe river basin, Ethiopia. Modeling Earth Systems and Environment, 2, 1-15.

Cramer, W., Guiot, J., Fader, M., Joaquim Garrabou, J., Gattuso, J. P., Iglesias, A., Lange, M. A., Lionello, P., Llasat, M. C., Paz, S., Peñuelas, J., Snoussi, M., Toreti, A., Michael N. Tsimplis, M. N., Elena Xoplaki, E., 2018. Climate change and inter-connected risks to sustainable development 
in the Mediterranean. Nature Climatic Change, 8, 972-980.

Flato, G.M., Boer, G.J., 2001. Warming Asymmetry in Climate Change Simulations. Geophysical Research Letters, 28, 195-198.

Gassman, P.W., Reyes, M.R., Green, C.H., Arnold, J.G., 2007. The Soil and water assessment tool: historical development, applications and future research directions. Economics Publications, 50(4), 1211-1250.

Gosain, A.K., Rao, S., Basuray, D., 2006. Climate change impact assessment on hydrology of Indian river basins. Current Science, 90(3), 346353.

Kara, F., Yucel, I., 2015. Climate change effects on extreme flows of water supply area in Istanbul: utility of regional climate models and downscaling method. Environmental Monitoring Assessment, 187(9), 580.

Kara, F., Ismail Yucel, I., Akyurek, Z., 2016. Climate change impacts on extreme precipitation of water supply area in Istanbul: use of ensemble climate modelling and geostatistical downscaling. Hydrological Sciences Journal, 61(14), 2481-2495.

Jahn, R., Blume, H. P., Asio, V. B., Spaargaren, O., Schad, P., 2006. Guidelines for soil description. 4th ed. Rome: Food and Agriculture Organization of the United Nations, pp. 67-77.

Jerry, M., Terese, T.C. Richmond, Gary W, Yohe Eds., 2014. Climate Change Impacts in the United States: The Third National Climate Assessment. U.S. Global Change Research Program, 841 p.

IPCC., 2000. Third Assessment Report, 2000 (Contribution of Working Group I and II to the Second Assessment Report of the Intergorvenmental Panel on Climate Change).

IPCC., 2014. AR5 Synthesis Report: Climate Change 2014, The Synthesis Report (SYR) of the IPCC Fifth Assessment Report (AR5).

Lionello, P., Scarascia, L., 2018. The relation between climate change in the Mediterranean region and global warming. Reg Environ Change, 18, 14811493.
Sattar H., Sarwar S., Shrestha S., 2020. Hydrologic Impact of Climate Change on Planned Hydro Dams in Swat River Basin. In: Mohd Sidek L., Salih G., Boosroh M. (eds) ICDSME 2019. ICDSME 2019. Water Resources Development and Management, Springer, Singapore.

Moriasi, D. N., Arnold, J. G., Van Liew, M. W., Bingner, R. L., Harmel, R. D., Veith, T. L., 2007. Model evaluation guidelines for systematic quantification of accuracy in watershed simulations. American Society of Agricultural and Biological Engineers, 50(3), 885-900.

Song, Y., Zhang, J., Zhang, M., 2018. Impacts of Climate change on runoff in Qujiang River Basin Based on SWAT Model. 7th International Conference on Agro-geoinformatics(Agrogeoinformatics), Hangzhou, pp. 1-5.

Nakicenovic, Alcamo, J., Davis, G., Vries, B.D., 2000. Special Report on Emissions Scenarios. A Special Report of Working Group III of the Intergovernmental Panel on Climate Change. Cambridge University Press: Cambridge. 599 p.

Nash, J. E., Sutcliffe, J. V., 1970. River flow forecasting through conceptual models: Part I. A discussion of principles. Journal of Hydrology, 10 (3), 282-290.

Oakes, H., 1958. Türkiye Toprakları. Türk Yüksek Ziraat Mühendisleri Birliği Neşriyatı. Sayı:18, 224 s.

Ozdemir, A., Leloglu U.M., 2018. A fast and automated hydrologic calibration tool for SWAT. Water and Environmental Journal, 33, 488-498.

Otto, Daniel R., 2019. The impact of climate change on stream flow and watershed hydrology determined using the SWAT model in the Eastern Sierra Nevada Watershed. California. Senior Capstone Projects. 855 p.

Sönmez, A. Y., Kale, S., 2020. Climate change effects on annual streamflow of Filyos River (Turkey). Journal of Water and Climate Change, 11 (2), 420-433. jwc2018060. doi: https://doi. org/10.2166/wcc. 2018.060 . 
USDA., 1986. Urban hydrology for small watersheds. Technical Release 55(TR-55) (Second ed.). United States of Department of Agriculture, Natural Resources Conservation Service, Conservation Engineering Division.

Uniyal, B., Jha, M.K., Verma, A.K., 2015. Assessing climate change impact on water balance components of a river basin using swat model. Water Resour Manage, 29, 4767-4785.

Verma, S., Bhattarai, R., Bosch, N. S., Cooke, R. C., Kalita, P. K., Markus, M., 2015. Climate change impacts on flow, sediment and nutrient export in a Great Lakes Watershed using SWAT. CLEAN Soil, Air, Water, 43(11), 1464-1474.

Yagbasan, O., 2016. Impacts of climate change on groundwater recharge in Küçük Menderes River Basin in Western Turkey. Geodinamica Acta, 28(3), 209222. doi: 10.1080/09853111.2015.1121802.
Yagbasan, O., Yazicigil, H., Demir, V., 2017. Impacts of climatic variables on water-level variations in two shallow Eastern Mediterranean lakes. Environmental Earth Science, 76, 575.

Yilmaz K.K., Yazicigil H., 2011. Potential impacts of climate change on Turkish Water Resources: A Review. In: Baba A., Tayfur G., Gündüz O., Howard K., Friedel M., Chambel A. (eds) Climate Change and its Effects on Water Resources. NATO Science for Peace and Security Series C: Environmental Security, vol 3. Springer, Dordrecht.

YBOZHP., 2014. Yuvacık Baraj1 Havza Koruma ve Özel Hüküm Belirleme projesi. Kocaeli Büyükşehir Belediyesi Başkanlığı İzmit Su ve Kanalizasyon İdaresi Genel Müdürlüğü. 